\title{
THE TOTAL NON-PROTEIN NITROGEN AND THE UREA OF THE BLOOD IN HEALTH AND IN DISEASE, AS ESTIMATED BY FOLIN'S METHODS *
}

\author{
WILDER TIJESTON, M.D., AND C. W. COMFORT, JR., M.D. \\ NIE HAVI:N, CONN.
}

Ever since the time Prévost and Dumas, ${ }^{1}$ who in 1823, first demonstrated an increase of the urea of the blood after extirpation of the kidneys in animals, the total non-protein nitrogen and the urea of the blood have been the subject of repeated investigations, and have been accorded considerable importance in the diagnosis and prognosis of Bright's disease. Owing, however, to the fact that the methods employed have been various and more or less subject to error, the results obtained have been conflicting. This may be readily seen when we find that the total non-protein nitrogen in the normal person is given as anywhere from 25 to $60 \mathrm{mg}$. per hundred c.c. of blood. The brilliant methods recently devised by Folin ${ }^{2}$ render possible the accurate estimation of these substances in a small amount of blood, from 2 to 5 c.c. sufficing for all the analyses. The increase in accuracy depends on an improved method of removing the proteins from the blood, and the use of Nessler's solution makes it possible to work with small quantities of blood.

The term "non-protein nitrogen" explains itself. It includes all the nitrogenous substances remaining after the removal of the proteins by precipitation, in the case of Folin's method by means of methyl alcohol and later by zinc chlorid. Other names for it are "incoagulable nitrogen," "filtrate nitrogen," "rest," "waste" or "retention nitrogen."

Folin's method for total non-protein nitrogen is essentially a "micro-Kjeldahl" process, in which the ammonia after neutralization of the products of digestion is blown over into a collecting vessel by a current of air instead of by distillation, and is estimated by the use of Nessler's solution and the colorimeter as in water analysis. His method for urea depends on the quantitative breaking down of this substance to ammonia at a temperature of $150 \mathrm{C}$., and its subsequent estimation in the same manner as the total nitrogen. The figures

* Submitted for publication Aug. 11, 1914.

* From the Department of Medicine, Yale University Medical School.

* Read in abstract at the meeting of the Association of American Physicians, May 13, 1914.

1. Prévost and Dumas: Ann. de chimie et de physique, 1823, xxiii, 90.

2. Folin, O., and Denis, W.: Jour. Biol. Chem., 1912, xi, 527. 
obtained represent urea estimated as nitrogen, and include the ammonia nitrogen, which, however, is so small in normal blood, and presumably in most forms of disease, as to be negligible.

These new methods of Folin open up great possibilities both in the line of experimental research and in clinical work, and promise to throw new light on many problems connected with the function of the kidneys.

The present investigation was undertaken with the view of determining the non-protein nitrogen and the urea of the blood in a large series of miscellaneous diseases, paying special attention of course to affections of the kidneys. In this way it was hoped to gain a more exact idea as to the diagnostic and prognostic value of such determinations. The figures of previous investigators along these lines, of whom Strauss, ${ }^{3}$ Hohlweg ${ }^{4}$ and Widal $^{5}$ are especially deserving of mention, are not comparable to those cbtained by Folin's methods, for reasons already given. The work of the French school is especially inaccurate, depending on the very faulty hypobromite method for the urea estimation, a method which Rowntree and $\mathrm{Fitz}^{6}$ have shown to involve an error of from 10 to 60 per cent. We shall consider the results obtained by others working with the new Folin methods later on.

Before passing to a detailed account of our work, however, we cannot refrain from alluding to a practice of which $H$. Strauss has been guilty. This author, to whom we owe so much in the investigation of Bright's disease, has published as his own ${ }^{7}$ a slight modification of Folin's method for total nitrogen, giving Folin credit only for devising the method of removing the albumin. His method is word for word the same as Folin's up to the stage of combustion, where he substitutes an ordinary Kjeldahl determination on a large amount of filtrate for Folin's "micro-Kjeidahl” process. His offense is rendered more flagrant by the fact that he went to Folin's laboratory to learn Folin's method before publishing his article.

\section{TECHNIC}

We have followed very closely the original technic as described by Folin and Denis, ${ }^{2}$ and learned by one of us (Tileston) in Professor Folin's laboratory. The material has consisted of whole blood, oxa-

3. Strauss, H.: Die chronische Nierenentzündungen in ihrer Einwirkung auf die Blutflüssigkeit, Berlin, 1902; also Deutsch. Arch. f. klin. Med., 1912, cvi, 219.

4. Hohlweg, H.: Deutsch. Arch. f. klin. Med., 1911, civ, 216.

5. Widal, F.: Bull. et mém. Soc. méd. đ. hôp. de Paris, 1911, xxxii, 627. (And many other articles.)

6. Rowntree, L. G., and Fitz, R.: The Archives Int. Med., 1913, xi, 258.

7. Strauss, H.: Ztschr. f. Urol., 1913, vii, 287. 
lated, and the results have been calculated as milligrams of nitrogen per 100 c.c. of blood. In order to avoid the effects of the ingestion of protein, the blood has been drawn in the forenoon when possible. In cases with very large amounts of nitrogen we have found it advantageous to take 2 c.c. instead of 5 c.c. of the filtrate for analysis, and to dilute the specimens with water before adding Nessler's solution, thus avoiding turbidity. The determinations have been made in duplicate, with further controls in case the figures did not agree closely. The methods have proved accurate and reliable in our hands, and for any one with an eye for color, are not much more difficult to learn than the ordinary Kjeldahl method.

\section{THE TOTAL NON-PROTEIN NITROGEN AND THE UREA IN HEALTH}

Folin and Denis, ${ }^{8}$ working with the new methods, found in a series of sixteen healthy adults the total non-protein nitrogen varying within narrow limits, from 22 to $26 \mathrm{mg}$. per 100 c.c. of blood, while the urea nitrogen was exactly half as much, from 11 to $13 \mathrm{mg}$. The blood was taken in the forenoon, from three to six hours after breakfast. The figures given by previous investigators, as already mentioned, are all too high by reason of faulty methods.

TABLE 1.-NORMAL *

\begin{tabular}{|c|c|c|c|c|c|}
\hline \multirow[b]{2}{*}{ Case } & \multirow[b]{2}{*}{ Age } & \multicolumn{2}{|c|}{ Tota1 Nitrogen (mg.) } & \multicolumn{2}{|c|}{ Urea Nitrogen (mg.) } \\
\hline & & $\begin{array}{l}\text { After } \\
\text { fasting } \\
12 \text { hrs. }\end{array}$ & $\begin{array}{c}21 / 2 \text { hrs. } \\
\text { after heavy } \\
\text { meal }\end{array}$ & $\begin{array}{l}\text { After } \\
\text { fasting } \\
12 \text { hrs. }\end{array}$ & $\begin{array}{c}21 / 2 \text { hrs. } \\
\text { after heavy } \\
\text { meal }\end{array}$ \\
\hline $\begin{array}{l}\text { D. G. R. } \ldots \cdots \cdots \\
\text { L. V. G. } \cdots \cdots \cdots \cdots \\
\text { E. M. J. } \cdots \cdots \cdots \cdots \\
\text { C. W. C. } \cdots \cdots \cdots \cdots \\
\text { W. T. } \cdots \cdots \cdots \cdots \cdots\end{array}$ & $\begin{array}{l}24 \\
26 \\
27 \\
29 \\
39\end{array}$ & $\begin{array}{l}22.9 \\
25.0 \\
23.7 \\
23.8 \\
23.2\end{array}$ & $\begin{array}{l}25.9 \\
27.9 \\
29.5 \\
32.3 \\
26.4\end{array}$ & $\begin{array}{l}12.0 \\
13.6 \\
12.6 \\
14.1 \\
12.3\end{array}$ & $\begin{array}{l}13.6 \\
14.5 \\
15.1 \\
20.9 \\
13.1\end{array}$ \\
\hline
\end{tabular}

* In this and the following tables, the figures for total nitrogen and for urea nitrogen represent milligrams per 100 c.c. of blood.

In order to study the influence of diet, we examined five healthy male adults, early in the morning after a twelve-hours fast, and again in the afternoon of the same day, two and one-half hours after a meal containing a large amount of meat. The urine was normal in all these persons. As will be seen by a glance at Table 1, our fasting figures agree very closely with those of Folin, the nitrogen varying from 23 to $25 \mathrm{mg}$., and the urea from 12 to $14 \mathrm{mg}$. The effect of a heavy protein meal is seen to be a rise in the non-protein nitrogen of from 2.9 to $8.5 \mathrm{mg}$., averaging $4.7 \mathrm{mg}$., and a rise in the urea averaging

8. Folin and Denis: Jour. Biol. Chemistry, 1913, xiv, 33. 
$2.5 \mathrm{mg}$. One of our subjects (C. W. C.), who ate a great deal of meat, shows such a divergence from the others that an abnormality of the renal function seems possible, though the urine was negative. Not only did the nitrogen rise to a high figure after the meal $(32 \mathrm{mg}$.), but the urea amounted to considerably more than one-half the total nitrogen ( 65 per cent.).

The results show the need of considering the ingestion of food in interpreting the results of blood analysis, and the advisability of taking the blood either fasting or before the chief meal of the day. Further studies along these lines are desirable.

\section{THE TOTAL NON-PROTEIN NITROGEN AND THE UREA IN DISEASE}

One hundred and forty-two cases of disease of one sort or another have been studied. For the purpose of classification they have been divided into eleven groups, as follows: (1) chronic nephritis; (2) other diseases of the kidneys and of the genito-urinary tract; (3) leadpoisoning; (4) the complications of pregnancy; (5) acute intestinal obstruction; (6) diseases of the heart and aorta; $(7)$ the acute infections; (9) syphilis; (9) tuberculosis; (10) diseases of the nervous system; (11) miscellaneous diseases. These will be taken up in order.

For practical purposes figures for nitrogen below $30 \mathrm{mg}$. may be considered normal; those from 30 to 35 slightly, from 35 to 50 considerably, and from 50 to 100 greatly increased. One hundred milligrams or more, as we shall see later, constitutes a very dangerous elevation of the waste nitrogen. In the case of urea nitrogen, anything over $16 \mathrm{mg}$. is probably abnormal, and above $25 \mathrm{mg}$. considerably increased.

In the tables the figures for total nitrogen and urea nitrogen represent milligrams per hundred c.c. of blood. The abbreviations are explained ander Table 2 .

\section{CHRONIC NEPHRITIS}

A. Chronic Interstitial Nephritis.-In this disease we find figures varying all the way from normal to the enormous amount of $324 \mathrm{mg}$. for the nitrogen and $237 \mathrm{mg}$. for the urea. The seventeen cases fall naturally into two groups, those with normal or slightly elevated figures, and those with a marked increase. In the former, with one exception (Case 7), we have found a complete absence of all symptoms referable to renal insufficiency, although the hypertension in some was of long standing. These patients were mostly of the elderly, arteriosclerotic type. In the group with high nitrogen and urea, more or less pronounced symptoms of uremia have been present in all, excepting the border-line case, No. 12, with $57 \mathrm{mg}$. nitrogen. Of the six 
patients with over $100 \mathrm{mg}$. of nitrogen, five died within a period of 35 days, the sixth (Case 13) who came into the hospital with wellmarked symptoms of chronic uremia, and $80 \mathrm{mg}$. of nitrogen, became worse at first, and the retention nitrogen rose to $102 \mathrm{mg}$.; then improvement set in, and he left the hospital in fair condition at the end of two months, with a blood nitrogen of $70 \mathrm{mg}$. But the improvement was only temporary. He has just entered the hospital again with the old symptoms, and a blood nitrogen of $88 \mathrm{mg}$. fourteen weeks after the first examination. $\rightarrow$ Farr and Austin ${ }^{9}$ report a still more striking case (No. 31 of their series) of uremia with delirum tremens in which the nitrogen fell from $181 \mathrm{mg}$. to $36 \mathrm{mg}$. under treatment, and the patient was discharged in good shape. The subsequent history of these patients would be interesting. Javal ${ }^{10}$ states that such patients usually relapse and die within a few months, and reports ${ }^{11}$ one patient surviving eight months and still alive, as extremely exceptional.

We have encountered no case of uremia of the asthenic type, that is, with weakness and apathy, and gastro-intestinal symptoms-which has not shown a very marked increase of retention nitrogen. The great importance of blood analysis in the diagnosis of uremia, and in the prognosis of chronic nephritis, is evident from these facts.

The single case of uremia without retention of nitrogen (Case 7) calls for a more detailed description. The patient, a woman 64 years old, entered the hospital in a stuporous condition, a few hours after an epileptiform attack. The urine was consistent with the diagnosis of chronic nephritis; the systolic blood-pressure was $205 \mathrm{~mm}$. and fell to 185 after venesection. No more convulsions occurred and the next day the patient was better and clear mentally. Eleven days later she was discharged in good condition. There was a history of an attack of unconsciousness, probably without convulsions, ten months previously. In the absence of evidence pointing to epilepsy, alcoholism or syphilis, it seems reasonable to attribute the convulsion to nephritis. The non-protein nitrogen was 31.5 , the urea 16.4 on the day of entrance; the phthalein output was 42 per cent. There was evidently no renal insufficiency. This case fits in with the epileptiform type of uremia described recently by Reiss, ${ }^{12}$ in which there are convulsions exactly resembling those of epilepsy, with euphoria in the intervals, no increase in the non-protein nitrogen of the blood and no deficiency

$\dagger$ Note on reading proof: This patient died Aug. 11, 1914, of uremia, eightyeight days after the nitrogen reached $100 \mathrm{mg}$.

9. Farr, C. B., and Austin, J. H.: Jour. Exper. Med., 1913, xviii, 228.

10. Javal, A.: Bull. et Mém. Soc. méd. d. hôp. de Paris, 1911, xxxii, 485.

11. Mosny, Javal and Levy-Bruhl: Bull. et mém. Soc. méd. d. hôp. de Paris, 1911, xxxii, 374 .

12. Reiss, E.: Ztschr. f. klin. Med., 1914, 1xxx, 97. 
in renal function. Such cases have been described by other authors, and Strauss pertinently asks if they are to be considered as truly of uremic origin.

B. Chronic Diffuse Nephritis.-We have examined only two cases of this disease. The first (Case 18) showed anasarca at entrance, with large amounts of albumin in the urine. The total nitrogen was normal and the urea unusually low ( 35 per cent. of the total nonprotein nitrogen); there were no uremic symptoms. The normal nitrogen figures frequently encountered in chronic diffuse nephritis have been ascribed to the hydremia or dilution of the blood. That this is not necessarily so was shown by later examination in this case after the edema had disappeared; the nitrogen was even lower than before. The second case (No. 19) entered the hospital with moderate edema, a normal blood-pressure and mild uremic symptoms. During his long stay the nitrogen gradually rose from $55 \mathrm{mg}$. to $67 \mathrm{mg}$. five weeks later, then rapidly to $174 \mathrm{mg}$. the day before his death from uremia, five months after the first examination. Meanwhile the bloodpressure rose to over $200 \mathrm{~mm}$. and he developed a high grade of albuminuric retinitis. At the autopsy there was a marked chronic nephritis with hypertrophy of the heart (weight $600 \mathrm{gm}$.) and moderately advanced tuberculosis of the lungs. The combined weight of the kidneys was $300 \mathrm{gm}$. Microscopically, there was very extensive glomertular disease; the tubules were dilated and filled with casts, and here and there showed degeneration and desquamation of the epithelium; there was a dense infiltration of the interstitial tissue with lymphoid cells.

The single case of amyloidosis (No. 20) showed practically normal figures.

C. Acute Nephritis.-Of this disease we have but one example to report, a case of acute arsenical poisoning ending in recovery (Case 21, Table 3). Two days after taking a large dose of Paris green the nitrogen was $70 \mathrm{mg}$. and the urea $58 \mathrm{mg}$. With convalescence the figures sank to normal. There was no edema. This case is comparable to the experimental uranium nephritis investigated by Frothingham, ${ }^{14}$ who found a marked increase of retention products at the height of the disease.

Before leaving the subject of Bright's disease we wish to discuss the relationship of albuminuric retinitis to retention. Widal ${ }^{15}$ claims that this condition is always an evidence of azotemia, which is his

13. Strauss, H.: Deutsch. Arch. f. klin. Med., 1912, cvi, 219.

14. Frothingham, C., Fitz, R., Folin, Otto, and Denis, W.: The Relation Between Non-Protein Nitrogen Retention and Phenolsulphonephthalein Excretion in Experimental Uranium Nephritis, The Archives Int. Med., 1913, xii, 245.

15. Widal, F.: Presse méd., 1912, xx, 973. 
TABLE 2.-

\begin{tabular}{|c|c|c|c|c|c|c|c|c|}
\hline \multirow[b]{2}{*}{$\begin{array}{l}\text { Case } \\
\text { No. }\end{array}$} & \multirow[b]{2}{*}{ Sex } & \multirow[b]{2}{*}{ Age } & \multirow[b]{2}{*}{ Diagnosis } & \multirow{2}{*}{$\begin{array}{c}\text { Sys- } \\
\text { tolic } \\
\text { Blood- } \\
\text { Pressure } \\
\text { mm. } \\
\text { Hg }\end{array}$} & \multicolumn{4}{|c|}{ Urine } \\
\hline & & & & & $\begin{array}{l}\text { Phenol- } \\
\text { sulphone- } \\
\text { phthalein } \\
\% \text { in } 2 \text { hrs. }\end{array}$ & $\begin{array}{l}\text { Amt. } \\
\text { c.c. } \\
\text { in } 24 \\
\text { hours }\end{array}$ & Sp. Gr. & Alb. \\
\hline 1 & M & 41 & Chronic interstitial & 180 & 66 & 1,300 & 1.017 & S.P.T. \\
\hline 2 & $\mathrm{~F}$ & 62 & Chronic interstitial . & 195 & . & 600 & 1.023 & S.P.T. \\
\hline 3 & $\mathrm{~F}$ & 52 & Chronic interstitial .. & 210 & 40 & (?) 390 & 1.019 & S.P.T. \\
\hline 4 & $\mathrm{~F}$ & 75 & Chronic interstitial & 210 & 38 & 460 & 1.019 & S.P.T. \\
\hline 5 & $\mathrm{~F}$ & 66 & Chronic interstitial. & 220 & 38 & S.S. & $1: 012$ & S.P.T. \\
\hline 6 & M & 65 & Chronic interstitial ... & 200 & .. & S. S. & 1.030 & S.P.T. \\
\hline 7 & $\mathrm{~F}$ & 64 & Chronic interstitial ... & 205 & 42 & 1,050 & 1.020 & V.S.T. \\
\hline 8 & $\mathrm{~F}$ & 46 & Chronic interstitial .... & 180 & 50 & 520 & 1.019 & V.S.T. \\
\hline 9 & $\mathrm{~F}$ & 61 & Chronic interstitial ..... & 250 & .. & S.S. & 1.010 & S.P.T. \\
\hline 10 & $\mathrm{~F}$ & 63 & $\begin{array}{l}\text { Chronic interstitial, with } \\
\text { albuminuric retinitis }\end{array}$ & 185 & .. & 2,040 & 1.018 & V.S.T. \\
\hline 11 & $\mathrm{~F}$ & 53 & Chronic interstitial ...... & 240 & . & 2,000 & 1.007 & S.P.T. \\
\hline 12 & $\mathrm{~F}$ & 24 & $\begin{array}{l}\text { Chronic interstitial, with } \\
\text { cholelithiasis }\end{array}$ & $\ldots$ & 80 & 650 & 1.014 & S.T. \\
\hline 13 & $\mathbf{M}$ & 48 & $\begin{array}{l}\text { Chronic interstitial, with } \\
\text { uremia }\end{array}$ & 240 & $\begin{array}{l}22 \\
\ddot{26}\end{array}$ & 530 & 1.016 & V.S.T. \\
\hline 14 & M & 25 & $\begin{array}{l}\text { Chronic interstitial with } \\
\text { albuminuric retinitis }\end{array}$ & 212 & 0.0 & $279+$ & 1.011 & $0.8 \%$ \\
\hline 15 & M & 55 & $\begin{array}{l}\text { Chronic interstitial, with } \\
\text { uremia }\end{array}$ & 210 & 0.5 & 730 & 1.010 & S.T. \\
\hline 16 & $\mathbf{M}$ & 22 & $\begin{array}{l}\text { Chronic interstitial, with } \\
\text { uremia }\end{array}$ & 180 & 0.5 & 1,030 & 1.014 & S.T. \\
\hline 17 & $\mathbf{M}$ & 25 & $\begin{array}{l}\text { Chronic interstitial with } \\
\text { uremia }\end{array}$ & 175 & 0.0 & S.S. & 1.010 & $\mathrm{~T}$. \\
\hline 18 & $\mathrm{~F}$ & 20 & Chronic diffuse & 132 & 43 & 420 & 1.030 & $2.0 \%$ \\
\hline 19 & M & 25 & Chronic diffuse .. & 146 & 5 & 960 & 1.016 & $0.4 \%$ \\
\hline & & & & 210 & 0.0 & 1,440 & 1.010 & H. T. \\
\hline 20 & $\mathbf{M}$ & 44 & Amyloidosis & $\ldots$ & 55 & S.S. & 1.026 & S.T. \\
\hline
\end{tabular}

* The following abbreviations are employed in this and the following tables: S.S. S. T. = slight trace, T. = trace, H.T. = heavy trace, W. B.C. = white blood-corEsbach method, and represent percentages. 


\begin{tabular}{|c|c|c|c|c|}
\hline Urine & \multirow[b]{2}{*}{ Diet } & \multicolumn{2}{|c|}{ Blood } & \multirow[b]{2}{*}{ Remarks } \\
\hline Microscopical & & $\begin{array}{c}\text { Total } \\
\mathrm{N} . \\
(\mathrm{mg} .)\end{array}$ & $\begin{array}{c}\text { Urea } \\
\text { N. } \\
(\mathrm{mg} .)\end{array}$ & \\
\hline $\begin{array}{l}\text { Few hyaline casts; } \\
\text { W. B. C. }\end{array}$ & Mixed & 23.0 & 11.4 & Early process in kidneys. Wassermann + \\
\hline $\begin{array}{l}\text { Numerous hyaline } \\
\text { casts: few R. B.C. }\end{array}$ & Mixed & 23.2 & 11.1 & Recent attack of cardiac decompensation. \\
\hline $\begin{array}{l}\text { Rare hyaline cast; } \\
\text { few W.B.C. }\end{array}$ & Mixed & 27.4 & 13.4 & \\
\hline $\begin{array}{l}\text { Few hyaline, gran- } \\
\text { ular casts; W.B.C. }\end{array}$ & Mixed & 28.2 & 14.6 & No symptoms. \\
\hline Pus $\ldots \ldots \ldots \ldots \ldots$ & $\begin{array}{l}\text { Moderate } \\
\text { protein } \\
\text { Poor pro. }\end{array}$ & $\begin{array}{l}29.0 \\
25.3\end{array}$ & $\begin{array}{l}16.1 \\
\cdots\end{array}$ & $\begin{array}{l}\text { Complicated with cystitis. Acute pyelitis } \\
\text { several months ago. Cerebral hemor } \\
\text { rhages } 1 \text { year and again } 1 \text { month ago. }\end{array}$ \\
\hline - & $\begin{array}{l}\text { tein, } 1 \text { day } \\
\text { Mixed }\end{array}$ & 29.7 & 16.1 & $\begin{array}{l}\text { Entered for epistaxis. No sign of renal } \\
\text { insufficiency. }\end{array}$ \\
\hline $\begin{array}{l}\text { Rare hyaline casts; } \\
\text { W. B. C. }\end{array}$ & Mixed & 31.5 & 16.4 & $\begin{array}{l}\text { One epileptiform convulsion a few hours } \\
\text { previous. Prompt recovery after vene- } \\
\text { section, without any more fits. }\end{array}$ \\
\hline $\begin{array}{l}\text { Occasional coarse } \\
\text { granular cast; } \\
\text { many W. B. C. }\end{array}$ & Soft & 31.7 & 15.4 & $\begin{array}{l}\text { Subacute appendicitis recently. Early } \\
\text { process in kidney. }\end{array}$ \\
\hline $\begin{array}{l}\text { Very few hyaline } \\
\text { casts; some R.B.C. }\end{array}$ & Mixed & 31.7 & 16.7 & $\begin{array}{l}\text { Blood-pressure over } 200 \text { for past } 4 \text { years } \\
\text { Never any symptoms of uremia. }\end{array}$ \\
\hline $\begin{array}{l}\text { Occasional hyaline } \\
\text { cast; many R.B.C. }\end{array}$ & Mixed & 32.0 & 17.7 & $\begin{array}{l}\text { Albuminuric retinitis of moderate inten } \\
\text { sity, one year's duration. }\end{array}$ \\
\hline Rare hyaline cast & Mixed & 35.3 & . & $\begin{array}{l}\text { Hypertension for several years. No sign } \\
\text { of renal insufficiency. }\end{array}$ \\
\hline $\begin{array}{l}\text { Hyaline, occasional } \\
\text { granular casts; } \\
\text { W. B. C. }\end{array}$ & $\begin{array}{l}\text { Soft } \\
\text { Low pro- } \\
\text { tein, } 6 \text { days }\end{array}$ & $\begin{array}{l}57.5 \\
24.2\end{array}$ & $\begin{array}{l}27.7 \\
12.5\end{array}$ & $\begin{array}{l}\text { Recent attack of gall-stone colic. } \\
\text { No symptoms of uremia. }\end{array}$ \\
\hline $\begin{array}{l}\text { Hyaline, granular } \\
\text { casts; R. B. C.; } \\
\text { W. B. C. }\end{array}$ & Mixed & $\begin{array}{r}79.5 \\
102.2 \\
70.5 \\
87.5\end{array}$ & $\begin{array}{l}55.1 \\
79.5 \\
40.4 \\
53.1\end{array}$ & $\begin{array}{l}4 / 29 / 14 \text { Lead poisoning probable. Symp } \\
5 / 15 / 14 \text { toms of chronic uremia. Left } \\
6 / 21 / 14 \text { hospital improved after } 2 \text { mos } \\
8 / 8 / 14 \text { Returned in } 6 \text { weeks in same con } \\
\text { dition as before. }\end{array}$ \\
\hline $\begin{array}{l}\text { Hyaline, granular } \\
\text { casts; R. B. C.; } \\
\text { W. B. C. }\end{array}$ & Milk & 151.2 & 109.4 & $\begin{array}{l}\text { Probably secondary contracted kidney } \\
\text { Slight edema, headache, vomiting, blur } \\
\text { red vision. Died } 2 \text { days later. }\end{array}$ \\
\hline $\begin{array}{r}\text { Hyaline, granular } \\
\text { casts; many } \\
\text { R. B. C.; W. B. C. }\end{array}$ & Mixed & $\begin{array}{l}188.7 \\
286.2\end{array}$ & $\begin{array}{l}141.0 \\
191.0\end{array}$ & $\begin{array}{l}4 / 23 / 14 \text { Symptoms of chronic uremia at } \\
5 / 13 / 14 \text { entrance. Died uremic } 35 \text { days } \\
\text { after first analysis. }\end{array}$ \\
\hline $\begin{array}{l}\text { Few hyaline, granu- } \\
\text { lar casts; R.B.C. } \\
\text { W. B. C. }\end{array}$ & $\begin{array}{l}\text { Low pro- } \\
\text { tein, } 5 \text { da., } \\
\text { mixed, } 3 \\
\text { days }\end{array}$ & $\begin{array}{l}220.0 \\
232.5 \\
324.0\end{array}$ & $\begin{array}{l}143.0 \\
184.0 \\
237.0\end{array}$ & $\begin{array}{l}\text { 3/10/14 Entered with symptoms of } \\
3 / 13 / 14 \text { chronic uremia. Second entrance } \\
3 / 27 / 14 \text { 3/27/14. Died in coma } 2 \text { days after } \\
\text { last analysis. Necropsy: small granu } \\
\text { lar kidneys, combined weight, } 105 \mathrm{gm}\end{array}$ \\
\hline $\begin{array}{l}\text { Few hyaline, granu- } \\
\text { ular, epithelial } \\
\text { casts; W. B.C. }\end{array}$ & Liquid & 313.0 & 205.0 & $\begin{array}{l}\text { Died next day in coma, preceded by con } \\
\text { vulsions. }\end{array}$ \\
\hline $\begin{array}{l}\text { Many hyaline, gran- } \\
\text { ular casts; R.B.C. } \\
\text { W. B. C. }\end{array}$ & $\begin{array}{l}\text { Soft } \\
\text { Salt free, } \\
5 \text { weeks }\end{array}$ & $\begin{array}{l}26.7 \\
22.6\end{array}$ & $\begin{array}{r}10.7 \\
8.0\end{array}$ & $\begin{array}{l}\text { 2/13/14 Considerable edema at first anal } \\
3 / 19 / 14 \text { ysis; none at second. Discharged } \\
\text { improved, } 4 / 29 / 14 \text {. }\end{array}$ \\
\hline $\begin{array}{l}\text { Many hyaline, gran- } \\
\text { ular casts; R.B.C. } \\
\text { W. B. C. }\end{array}$ & Mixed & $\begin{array}{r}55.2 \\
67.0 \\
140.6 \\
173.7\end{array}$ & $\begin{array}{r}31.5 \\
49.0 \\
113.1 \\
131.3\end{array}$ & $\begin{array}{l}\text { 1/26/14 At first admission, occasional } \\
3 / 7 / 14 \text { slight symptoms of uremia, head } \\
5 / 16 / 14 \text { ache, dizziness, nausea, vomiting } \\
5 / 20 / 14 \text { Moderate general edema. Tuber } \\
\text { culosis of lungs, 2d stage. Second admis } \\
\text { sion } 5 / 9 / 14 \text {, with pronounced uremic } \\
\text { symptoms and albuminuric retinitis } \\
\text { Died uremic, } 5 / 21 / 14 \text {. Necropsy showed } \\
\text { very extensive disease of glomeruli } \\
\text { tubules and interstitial tissue. }\end{array}$ \\
\hline & Mixed & 33.9 & 15.3 & $\begin{array}{l}\text { Enlarged liver and spleen; osteomyelitis } \\
\text { with discharging sinuses for } 1 \text { year. }\end{array}$ \\
\hline
\end{tabular}

$=$ single specimen, S.P.T. = slightest possible trace, V.S.T., = very slight trace; puscles, R.B.C. = red blood-corpuscles; the figu res for albumin were obtained by the 
TABLE 3.-Other Diseases of-

\begin{tabular}{|c|c|c|c|c|c|c|c|c|}
\hline \multirow[b]{2}{*}{$\begin{array}{l}\text { Case } \\
\text { No. }\end{array}$} & \multirow[b]{2}{*}{ Sex } & \multirow[b]{2}{*}{ Age } & \multirow[b]{2}{*}{ Diagnosis } & \multirow{2}{*}{$\begin{array}{c}\text { Sys- } \\
\text { tolic } \\
\text { Blood- } \\
\text { Pressure } \\
\mathrm{mm} . \\
\mathrm{Hg}\end{array}$} & \multicolumn{4}{|c|}{ Urine } \\
\hline & & & & & $\begin{array}{c}\text { Phenol- } \\
\text { sulphone- } \\
\text { phthalein } \\
\% \text { in } 2 \text { hrs. }\end{array}$ & $\begin{array}{l}\text { Amt. } \\
\text { c.c. } \\
\text { in } 24 \\
\text { hours }\end{array}$ & Sp.Gr. & Alb. \\
\hline 21 & M & 48 & Acute nephritis & 85 & 48 & 590 & 1.013 & V.S.T. \\
\hline 22 & $\mathbf{M}$ & 58 & Chronic passive conges- & 128 & 70 & $450+$ & 1.022 & S.P.T. \\
\hline 23 & M & 54 & $\begin{array}{l}\text { Chronic passive conges- } \\
\text { tion }\end{array}$ & 170 & 49 & 850 & 1.024 & V.S.T. \\
\hline 24 & M & 58 & Chronic passive conges- & 120 & 50 & 1,660 & 1.011 & S.P.T. \\
\hline 25 & M & 45 & $\begin{array}{c}\text { Chronic passive conges- } \\
\text { tion }\end{array}$ & 90 & 58 & 620 & 1.024 & V.S.T. \\
\hline 26 & M & 47 & Chronic passive conges- & 115 & 53 & 500 & 1.023 & S.T. \\
\hline 27 & M & 21 & Chronic passive conges- & 110 & 75 & 1,680 & 1.017 & S.P.T. \\
\hline 28 & $\mathrm{~F}$ & 16 & $\begin{array}{l}\text { Chronic passive conges- } \\
\text { tion }\end{array}$ & $\ldots$ & • & S.S. & 1.040 & H. T. \\
\hline 29 & $\mathrm{~F}$ & 27 & Pyelitis ... & 118 & 80 & 1,900 & 1.004 & S.P.T. \\
\hline 30 & $\mathrm{~F}$ & 19 & Pyelitis .... & 112 & 30 & 1,340 & 1.015 & V.S.T. \\
\hline 31 & $\mathrm{M}$ & 47 & Hypernephroma ........ & 125 & .. & 1,220 & 1.018 & S. T. \\
\hline 32 & $\mathrm{M}$ & 62 & $\begin{array}{l}\text { Stricture of urethra, with } \\
\text { acute ascending infect. }\end{array}$ & 180 & .. & S.S. & 1.030 & H. T. \\
\hline 33 & M & 63 & $\begin{array}{l}\text { Stricture of urethra, with } \\
\text { acute ascending infect. }\end{array}$ & $\ldots$ & .. & S.s. & 1.020 & $\mathbf{T}$. \\
\hline 34 & $\mathbf{M}$ & 69 & $\begin{array}{l}\text { Tuberculosis of genito- } \\
\text { urinary tract }\end{array}$ & 88 & 10 & 1,100 & 1.014 & S. T. \\
\hline 35 & $\mathrm{M}$ & 86 & Hypertrophied prostate & 85 & .. & $\ldots \ldots$ & $\ldots$. & $\ldots$ \\
\hline 36 & $\mathbf{M}$ & 77 & $\begin{array}{l}\text { Hypertrophied prostate } \\
\text { with retention }\end{array}$ & 142 & 60 & S.S. & 1.022 & $\mathrm{~T}$. \\
\hline 37 & M & 64 & $\begin{array}{l}\text { Carcinoma, prostate and } \\
\text { bladder }\end{array}$ & 110 & 10 & 1,180 & 1.017 & S.T. \\
\hline 38 & M & 70 & Carcinoma, bladder ...... & ... & 0.0 & ..... & $\cdots \cdots$ & ..... \\
\hline
\end{tabular}




\begin{tabular}{|c|c|c|c|c|}
\hline Urine & \multirow{2}{*}{ Diet } & \multicolumn{2}{|c|}{ Blood } & \multirow[b]{2}{*}{ Remarks } \\
\hline Microscopical & & $\begin{array}{c}\text { Total } \\
\text { N. } \\
(\mathrm{mg})\end{array}$ & $\begin{array}{c}\text { Urea } \\
\text { N. } \\
(\mathrm{mg} .)\end{array}$ & \\
\hline $\begin{array}{l}\text { Hyaline, granular, } \\
\text { pus casts; R. B.C. } \\
\text { W. B. C. }\end{array}$ & Soft & $\begin{array}{l}69.7 \\
29.5\end{array}$ & $\begin{array}{l}57.7 \\
15.7\end{array}$ & $\begin{array}{ll}4 / 25 / 14 & \text { Large dose of Paris green taken } \\
5 / 18 / 14 & 2 \text { days previously. Recovered. }\end{array}$ \\
\hline $\begin{array}{l}\text { Occasional hyaline } \\
\text { cast; W. B. C. }\end{array}$ & Karell & 24.6 & 13.7 & $\begin{array}{l}\text { Mitral regurgitation; cardiac decompen- } \\
\text { sation; marked edema. }\end{array}$ \\
\hline $\begin{array}{l}\text { Hyaline, granular } \\
\text { casts; R. B. C.; } \\
\text { W. B. C. }\end{array}$ & Karel1 & 25.0 & 13.8 & Aortic regurgitation; luetic aortitis. \\
\hline $\begin{array}{l}\text { Hyaline casts } \\
\text { W. B. C. }\end{array}$ & Soft & 30.6 & 16.9 & $\begin{array}{l}\text { Mitral regurgitation and chronic cardiac } \\
\text { decompensation. }\end{array}$ \\
\hline $\begin{array}{l}\text { Few hyaline, granu- } \\
\text { lar casts; W. B.C. }\end{array}$ & Mixed & 31.7 & 15.1 & $\begin{array}{l}\text { Mitral stenosis; failure of compensation } \\
\text { without edema. }\end{array}$ \\
\hline $\begin{array}{l}\text { Many hyaline casts; } \\
\text { R.B.C.; W. B.C }\end{array}$ & Karell & 34.4 & 17.5 & $\begin{array}{l}\text { Edema; extreme cyanosis; died } 2 \text { days } \\
\text { later. }\end{array}$ \\
\hline $\begin{array}{l}\text { Hyaline casts; few } \\
\text { R.B.C.; W. B.C. }\end{array}$ & Soft & 42.2 & 25.4 & $\begin{array}{l}\text { Mitral stenosis and regurgitation with } \\
\text { decompensation. }\end{array}$ \\
\hline $\begin{array}{l}\text { Many hyaline, gran- } \\
\text { ular casts; W.B.C. }\end{array}$ & Soft & 67.7 & 43.9 & $\begin{array}{l}\text { Blood taken a few hours before death } \\
\text { from failure of compensation, second- } \\
\text { ary to mitral disease. }\end{array}$ \\
\hline $\begin{array}{l}\text { Occasional hyaline } \\
\text { cast; pus }\end{array}$ & Soft & 26.5 & 14.9 & Acute febrile attack. \\
\hline $\begin{array}{l}\text { Rare hyaline cast; } \\
\text { R. B. C.; pus }\end{array}$ & $\begin{array}{l}\text { Liquid, } \\
\text { soft }\end{array}$ & $\begin{array}{l}70.7 \\
40.2\end{array}$ & 51.0 & $\begin{array}{l}6 / 16 / 14 \text { Complicated with pyelonephrosis } \\
6 / 26 / 14 \text { at entrance. }\end{array}$ \\
\hline $\begin{array}{l}\text { Many R. B. C.; } \\
\text { W. B. C. }\end{array}$ & Mixed & 33.5 & 18.2 & $\begin{array}{l}\text { Tumor involving nearly all of left kidney. } \\
\text { Removed later at operation. }\end{array}$ \\
\hline Much pus ........ & Liquid & 91.2 & 61.2 & $\begin{array}{l}\text { Died next day. Necropsy: extravasation } \\
\text { of urine; gangrenous cystitis with per- } \\
\text { foration of bladder; purulent pyelitis. }\end{array}$ \\
\hline $\begin{array}{l}\text { Many R. B. C. and } \\
\text { W. B.C. }\end{array}$ & Soft & 209.0 & 172.0 & $\begin{array}{l}\text { Hemorrhagic cystitis with putrid urine. } \\
\text { Died same day of asthenia; no convul- } \\
\text { sions. }\end{array}$ \\
\hline $\begin{array}{l}\text { R.B.C.; very many } \\
\text { W. B. C. }\end{array}$ & $\begin{array}{l}\text { Soft, with } \\
\text { meat once } \\
\text { daily } \\
\text { Liquid }\end{array}$ & 31.4 & 37.6 & $\begin{array}{l}\text { Entered hospital for retention. Tubercle } \\
\text { bacilli in urine. Location of disease un- } \\
\text { certain. Died } 8 \text { days after. } \\
\text { Prostatectomy next day. Died } 5 \text { days later. }\end{array}$ \\
\hline R. B. C.; W. B. C. & $\begin{array}{l}\text { Mixed } \\
\text { Low pro- } \\
\text { tein }\end{array}$ & $\begin{array}{l}48.7 \\
30.5\end{array}$ & $\begin{array}{l}37.6 \\
17.2\end{array}$ & $\begin{array}{l}3 / 13 / 14 \text { Prostatectomy } 5 \text { days after sec- } \\
4 / 1 / 14 \text { ond analysis. Recovered. }\end{array}$ \\
\hline R. B. C.; pus...... & Mixed & 41.0 & 24.3 & $\begin{array}{l}\text { Suprapubic drain in bladder before blood } \\
\text { examination. }\end{array}$ \\
\hline & Soft & $\begin{array}{l}58.2 \\
99.5\end{array}$ & $\begin{array}{l}45.5 \\
69.7\end{array}$ & $\begin{array}{l}\text { 4/10/14 Operation on second day after } \\
4 / 15 / 14 \text { second analysis. Bladder filled } \\
\text { with growth. Died } 4 \text { days later. }\end{array}$ \\
\hline
\end{tabular}


appropriate name for a marked increase of the nitrogenous waste products. That this is not always so is shown by our Case 10, in which a moderate grade of albuminuric retinitis of a year's duration was accompanied by normal figures for nitrogen and urea. Where the eye condition was advanced, however, we too have found marked azotemia.

\section{IJ. OTIIER DISEASES OF THE KIDNEYS AND OF THE GENITO- URINARY TRACT}

A. Chronic Passive Hyperemia of the Kidneys.-In this condition we have found either normal or moderately elevated figures, even in cases with extreme congestion (cf. Case 26). The one exception was a

TABLE 4.-

\begin{tabular}{|c|c|c|c|c|c|c|c|c|}
\hline \multirow[b]{2}{*}{$\begin{array}{l}\text { Case } \\
\text { No. }\end{array}$} & \multirow[b]{2}{*}{ Sex } & \multirow[b]{2}{*}{ Age } & \multirow[b]{2}{*}{ Diagnosis } & \multirow{2}{*}{$\begin{array}{c}\text { Sys- } \\
\text { tolic } \\
\text { Blood- } \\
\text { Pressure } \\
\mathrm{mm} . \\
\mathrm{Hg}\end{array}$} & \multicolumn{4}{|c|}{ Urine } \\
\hline & & & & & $\begin{array}{l}\text { Phenol- } \\
\text { sulphone- } \\
\text { phthalein } \\
\% \text { in } 2 \text { hrs. }\end{array}$ & $\begin{array}{l}\text { Amt. } \\
\text { c.c. } \\
\text { in } 24 \\
\text { hours }\end{array}$ & Sp. Gr. & Alb. \\
\hline 39 & $\mathrm{M}$ & 27 & Lead colic...$\ldots \ldots \ldots \ldots$ & 108 & .. & 650 & 1.025 & $\mathbf{T}$. \\
\hline 40 & $\mathrm{M}$ & 26 & Lead colic . & 160 & .. & 675 & 1.030 & S.P.T. \\
\hline 142 & $\mathrm{M}$ & 31 & Lead colic .... & 137 & 51 & 950 & 1.021 & S.P.T. \\
\hline 41 & M & 35 & Lead palsy & 153 & 50 & 1,360 & 1.018 & V.S.T. \\
\hline 42 & $\mathrm{M}$ & 36 & Lead colic ..... & 188 & .. & 620 & 1.022 & $0.05 \%$ \\
\hline 43 & $\mathbf{M}$ & 34 & Lead colic...$\ldots \ldots \ldots \ldots$ & $\cdots$ & . & S.S. & $\cdots \cdots$ & S.P.T. \\
\hline 44 & M & 63 & $\begin{array}{l}\text { Chronic plumbism, with } \\
\text { chronic interstitial ne- } \\
\text { phritis and uremia }\end{array}$ & 205 & . & S.S. & 1.020 & $0.2 \%$ \\
\hline
\end{tabular}

young girl with very marked failure of compensation; the blood was taken only a few hours before death, and showed $70 \mathrm{mg}$. of nitrogen. No autopsy was permitted. So far as can be judged from a small series of seven cases, the absence of retention is the rule in pure passive hyperemia, and its presence would indicate a complicating nephritis or possibly infarction.

$B$. Pyelitis.-In one of the two cases examined there was a considerable retention, amounting to $71 \mathrm{mg}$. of nitrogen. This case was complicated with pyonephrosis; the retention almost disappeared during convalescence. The other case, examined during the febrile stage 
showed normal figures. It seem probable that pyelitis in the absence of marked involvement of the kidney proper is not accompanied by azotemia.

C. Stricture of the Urethra, with Ascending Infection.-Two cases were encountered in this group. Both showed marked retention. The first patient (No. 32) suffered from extravasation of urine, the result of gangrenous cystitis with perforation of the bladder. The second (No. 33), a man with putrid hemorrhagic cystitis, the result of stricture, died with symptoms of uremia of the asthenic type. The blood nitrogen was excessively increased, measuring $209 \mathrm{mg}$.

D. Enlargement of the Prostate with Retention.-Two cases of simple hypertrophy of the prostate with retention of urine showed a

- Lead Poisoning

\begin{tabular}{|c|c|c|c|c|}
\hline Urine & & \multicolumn{2}{|c|}{ Blood } & \multirow[b]{2}{*}{ Remarks } \\
\hline Microscopical & Diet & $\begin{array}{c}\text { Total } \\
\mathrm{N} \\
(\mathrm{mg} .)\end{array}$ & $\begin{array}{l}\text { Urea } \\
\text { N. } \\
(\mathrm{mg} .)\end{array}$ & \\
\hline $\begin{array}{l}\text { Few hyaline, granu- } \\
\text { lar casts; R.B.C.; } \\
\text { W. B.C. }\end{array}$ & Liquid & 35.5 & 25.1 & First attack. \\
\hline $\begin{array}{l}\text { Many hyaline casts; } \\
\text { W. B. C. }\end{array}$ & Liquid & 38.4 & 29.2 & Attacks 2 years and again 1 week ago. \\
\hline $\begin{array}{l}\text { Occasional hyaline; } \\
\text { rare R. B. C. } \\
\text { W. B. C. }\end{array}$ & Mixed & 42.2 & 23.4 & Colic off and on for 2 years. \\
\hline $\begin{array}{l}\text { Few hyaline casts; } \\
\text { W. B. C. }\end{array}$ & Soft & 47.7 & 32.5 & Drop wrist. Similar attack 3 years ago. \\
\hline $\begin{array}{l}\text { Many hyaline, gran- } \\
\text { ular casts; } \\
\text { R. B. C.; W. B. C. }\end{array}$ & Soft & 51.5 & 29.2 & $\begin{array}{l}\text { First attack. Exposed to lead many } \\
\text { years. }\end{array}$ \\
\hline Hyaline, granular & Liquid & 54.0 & $\cdots$ & First attack 1 year ago. \\
\hline $\begin{array}{c}\text { casts } \\
\ldots \ldots \ldots \ldots \ldots \ldots\end{array}$ & Liquid & 99.0 & 71.6 & $\begin{array}{l}\text { Painter. Colic } 20 \text { years ago and last year. } \\
\text { Delirium and uremic coma. Autopsy: } \\
\text { small granular kidneys. }\end{array}$ \\
\hline
\end{tabular}

considerable increase of the blood nitrogen, up to $50 \mathrm{mg}$. One patient (No. 35) was operated on immediately and died five days later. The other was put on a low protein diet for five days, at the end of which time the nitrogen had fallen to normal. Prostatectomy was then performed and the patient made a good recovery. In a case of cancer of the bladder (Case 38 ) in which the nitrogen rose in five days from 58 to $99 \mathrm{mg}$., the patient was operated on soon after the second blood examination and died four days afterward. The cases are too few to draw conclusions from, but it seems probable that patients with a high blood nitrogen are poor operative risks and that better results will be 
attained by reducing the nitrogen by means of a diet poor in protein before operation.

\section{LEAD-POISONING}

The deleterious action of lead on the kidneys is clearly shown by the figures in Table 4. In every case there is a definite increase in nitrogen and urea, even in those entering hospital with their first attack of colic. All degrees of retention of waste products are seen, up to uremia (Case 44), the final event in so many cases of lead-poisoning.

TABLE 5.-Complications-

\begin{tabular}{|c|c|c|c|c|c|c|c|c|}
\hline \multirow{2}{*}{$\begin{array}{c}\text { Case } \\
\text { No. }\end{array}$} & \multirow[b]{2}{*}{ Age } & \multirow[b]{2}{*}{ Diagnosis } & \multirow{2}{*}{$\begin{array}{c}\text { Dura. } \\
\text { tion } \\
\text { of } \\
\text { Preg- } \\
\text { nancy } \\
\text { Mos. }\end{array}$} & \multirow{2}{*}{$\begin{array}{l}\text { Sys- } \\
\text { tolic } \\
\text { Blood- } \\
\text { Pressure } \\
\text { mm. } \\
\text { Hg }\end{array}$} & \multicolumn{4}{|c|}{ Urine } \\
\hline & & & & & $\begin{array}{l}\text { Phenol- } \\
\text { sulphone- } \\
\text { phthalein } \\
\% \text { in } 2 \text { hrs. }\end{array}$ & $\begin{array}{l}\text { Amt. } \\
\text { c.c. } \\
\text { in } 24 \\
\text { hours }\end{array}$ & Sp. Gr. & Alb. \\
\hline 45 & 35 & Eclampsia .. & 6 & 128 & 18 & $340+$ & 1.028 & V.S.T. \\
\hline $\begin{array}{l}46 \\
47\end{array}$ & \begin{tabular}{l|}
21 \\
26
\end{tabular} & $\begin{array}{l}\text { Eclampsia*.... } \\
\text { Eclampsia }\end{array}$ & 7 & $\begin{array}{l}118 \\
220\end{array}$ & $\begin{array}{l}65 \\
30\end{array}$ & $\begin{array}{r}680 \\
\text { S.S. }\end{array}$ & $\begin{array}{l}1.020 \\
1.028\end{array}$ & $\begin{array}{l}\text { V.S.T. } \\
\text { S.T. }\end{array}$ \\
\hline 48 & 28 & Eclampsia ... & 9 & $\ldots$ & .. & S.S. & 1.024 & H. T. \\
\hline 49 & 35 & Eclampsia, threatened. & 4 & 124 & 25 & 420 & 1.023 & S. T. \\
\hline 50 & 22 & Nephritis of pregnancy & 6 & 151 & 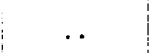 & 620 & 1.030 & $0.5 \%$ \\
\hline 51 & 25 & Nephritis of pregnancy & $71 / 2$ & 170 & $\ddot{59}$ & 350 & 1.032 & $1.2 \%$ \\
\hline 52 & 29 & $\begin{array}{l}\text { Hyperemesis } \\
\text { darum }\end{array}$ & 4 & 145 & 36 & 385 & 1.027 & V.S.T. \\
\hline 53 & $30:$ & $\begin{array}{c}\text { Hyperemesis } \\
\text { darum }\end{array}$ & 4 & $\ldots$ & .. & S.S. & 1.022 & $\mathrm{~T}$. \\
\hline
\end{tabular}

* Postpartum.

IV. THE COMPLICATIONS OF PREGNANCY

Farr and Williams, ${ }^{16}$ working with Folin's methods, have shown that the figures in normal pregnancy are practically the same as in the non-pregnant.

The eclampsia of pregnancy has often been compared with uremia, and even considered identical with it. The results of blood analysis, however, show that in a large proportion of the cases there is little or no retention of nitrogenous waste products in eclampsia, while in uremia there is almost invariably a very marked retention. Thus all

16. Farr, C. B., and Williams, P. F.: Am. Jour. Med. Sc., 1914, cxlvii, 556. 
of our four cases (Table 5) yielded figures for nitrogen below $40 \mathrm{mg}$., while six out of the seven cases of Farr and Williams were below $55 \mathrm{mg}$.; the seventh had $72 \mathrm{mg}$. In uremia we have found figures of $100 \mathrm{mg}$. or over in all but one of our cases.

This striking difference between the two conditions is of importance from the point of view of pathogenesis, indicating that eclampsia and uremia are quite distinct from one another. It is also of great

\begin{tabular}{|c|c|c|c|c|}
\hline Urine & & $\mathrm{B} 1 \mathrm{O}$ & pod & \\
\hline Microscopical & Diet & $\begin{array}{c}\text { Total } \\
\mathrm{N} \\
(\mathrm{mg} .)\end{array}$ & $\begin{array}{c}\text { Urea } \\
\text { N. } \\
(\mathrm{mg} .)\end{array}$ & Remarks \\
\hline $\begin{array}{l}\text { Many hyaline, gran- } \\
\text { ular casts }\end{array}$ & Milk & 25.0 & 14.1 & $\begin{array}{l}20 \text { convulsions in last } 48 \text { hours. Developed } \\
\text { acute mania. Recovered. Did not mis- } \\
\text { carry. }\end{array}$ \\
\hline Few hyaline casts & Liquid & 29.5 & 18.5 & Three convulsions to-day. Recovered. \\
\hline $\begin{array}{l}\text { Many hyaline, gran- } \\
\text { ular casts; } \\
\text { R. B. C.; W. B. C. }\end{array}$ & None & 32.2 & 14.8 & $\begin{array}{l}\text { Fifty convulsions in past } 24 \text { hours. Coma- } \\
\text { tose. Recovered. }\end{array}$ \\
\hline $\begin{array}{l}\text { Hyaline, granular } \\
\text { casts; W. B. C. }\end{array}$ & None & 39.7 & 19.9 & Typical case. Died 12 hours later. \\
\hline $\begin{array}{l}\text { Occasional R.B.C.; } \\
\text { W. B. C. }\end{array}$ & Mixed & 23.1 & 11.5 & $\begin{array}{l}\text { Para-7. Eclampsia with fifth pregnancy. } \\
\text { Induced labor for threatened eclampsia } \\
\text { with sixth pregnancy. Headache; scanty } \\
\text { urine. Discharged relieved. }\end{array}$ \\
\hline $\begin{array}{l}\text { Hyaline, granular } \\
\text { casts; W. B. C. }\end{array}$ & Soft & 28.9 & 14.1 & Headache; edema. Discharged relieved. \\
\hline $\begin{array}{l}\text { Hyaline, granular } \\
\text { casts; W. B. C. }\end{array}$ & Liquid & $\begin{array}{l}39.7 \\
24.7\end{array}$ & $\begin{array}{l}21.4 \\
12.6\end{array}$ & $\begin{array}{l}\text { First blood analysis, } 4 / 15 / 14 \text {. Delivered, } \\
4 / 18 / 14 \text {. Second analysis, } 4 / 29 / 14 \text {. Recov- } \\
\text { ered. }\end{array}$ \\
\hline $\begin{array}{l}\mathrm{H} \text { y a } 1 \text { in e cast } \\
\text { W. B. C. }\end{array}$ & Sof $\mathrm{t}$ & 20.7 & 8.0 & Vomiting for 9 weeks. Recovered. \\
\hline $\begin{array}{c}\text { Hyaline, granular } \\
\text { casts }\end{array}$ & None & 28.7 & 13.7 & Vomiting for 5 weeks. Died same day. \\
\hline
\end{tabular}

diagnostic value. The differential diagnosis of eclampsia from uremia has been up to the present in a highly unsatisfactory state, but with the aid of blood analysis it should now be possible with a high degree of probability.

In the peculiar condition known as the nephritis of pregnancy, we have found nearly normal values in two cases. Farr and Williams report three cases, of which two were practically normal; the third showed $52 \mathrm{mg}$. of nitrogen, falling to normal after delivery.

In hyperemesis we have found normal figures in two cases, one of them fatal, and Farr and Williams examined one case with the same result. 


\section{ACUTE INTESTINAL OBSTRUCTION}

In this condition we have found a remarkable increase in the nonprotein nitrogen and urea, as marked as in most cases of uremia. In one of the three cases the obstruction was mechanical, due to a band; in the other two it was of the paralytic variety. In a case of simple constipation examined for the sake of comparison, there was no retention, although the bowels had not moved for three days (Case 57). The complete disappearance of the retention in the two cases ending in recovery is evidence that the azotemia was not due to complicating disease of the kidneys.

TABLE 6.-ACUTE-

\begin{tabular}{|c|c|c|c|c|c|c|c|c|}
\hline \multirow[b]{2}{*}{$\begin{array}{l}\text { Case } \\
\text { No. }\end{array}$} & \multirow[b]{2}{*}{ Sex } & \multirow[b]{2}{*}{ Age } & \multirow[b]{2}{*}{ Diagnosis } & \multirow{2}{*}{$\begin{array}{c}\text { Sys- } \\
\text { tolic } \\
\text { Blood- } \\
\text { Pressure } \\
\text { mm. } \\
\text { Hg }\end{array}$} & \multicolumn{4}{|c|}{ Urine } \\
\hline & & & & & $\begin{array}{l}\text { Phenol- } \\
\text { sulphone- } \\
\text { phthalein } \\
\% \text { in } 2 \text { hrs. }\end{array}$ & $\begin{array}{l}\text { Amt. } \\
\text { c.c. } \\
\text { in } 24 \\
\text { hours }\end{array}$ & Sp.Gr. & Alb. \\
\hline 54 & $\mathrm{~F}$ & 70 & Strangulated hernia & $\ldots$ & $\begin{array}{l}25 \\
43\end{array}$ & 730 & 1.020 & V.S.T. \\
\hline 55 & $\mathrm{~F}$ & 26 & Acute obstruction & 116 & . & $500+$ & 1.011 & S.P.T. \\
\hline 56 & M & 60 & $\begin{array}{l}\text { Paralytic ileus, following } \\
\text { prostatectomy }\end{array}$ & 140 & 70 & S.S. & 1.028 & S. T. \\
\hline 57 & $\mathbf{F}$ & 21 & Simple constipation ..... & 124 & 77 & $380+$ & 1.022 & S.P.T. \\
\hline
\end{tabular}

The case of mechanical obstruction (No. 55) showed on the day of operation $92 \mathrm{mg}$. of nitrogen, and nine days later, although the obstruction had been relieved, $169 \mathrm{mg}$; death took place the following day. The postoperative symptoms in this case were delirium, vomiting, apathy and profound asthenia, symptoms strongly suggestive of uremia. No necropsy was permitted.

The two cases of paralytic ileus are very instructive, for they show that it is possible to recover from a very high degree of retention, provided that it is not too prolonged. In Case 56 the symptoms of acute intestinal obstruction developed two days after the operation of prostatectomy by the perineal route. Blood analysis the following day revealed $150 \mathrm{mg}$. of nitrogen and $92 \mathrm{mg}$. of urea. In spite of the alarming condition, recovery occurred, and the figures for nitrogen and urea fell to normal. 
In the other case of paralytic ileus (No. 54) following an operation for strangulated hernia, the blood was taken after improvement had begun, and showed $76 \mathrm{mg}$. of nitrogen, falling to normal later; it is probable the retention would have been more marked if the blood had been examined earlier.

The observation of a high degree of retention in acute intestinal obstruction is new, so far as we are aware. It suggests that some of the symptoms, such as profound asthenia and apathy, may be due to the retention of waste products.

In order to explain this striking phenomenon, it is necessary to recall the pathologic physiology of this condition.

-intestinal Obstruction

\begin{tabular}{|c|c|c|c|c|}
\hline Urine & & \multicolumn{2}{|c|}{ Blood } & \multirow[b]{2}{*}{ Remarks } \\
\hline Microscopical & Diet & $\begin{array}{c}\text { Total } \\
\text { N. } \\
(\mathrm{mg} .)\end{array}$ & $\begin{array}{c}\text { Urea } \\
\text { N. } \\
(\mathrm{mg} .)\end{array}$ & \\
\hline $\begin{array}{l}\text { Occasional hyaline } \\
\text { casts; few R.B.C.; } \\
\text { W. B. C. }\end{array}$ & $\begin{array}{l}\text { Liquid } \\
\text { Mixed }\end{array}$ & $\begin{array}{l}76.1 \\
29.2\end{array}$ & $\begin{array}{l}45.5 \\
15.2\end{array}$ & $\begin{array}{l}\text { Operation, } 4 / 6 / 14 \text {. Paralytic ileus, } 4 / 10 / 14 \text {. } \\
\text { Blood taken } 3 \text { days later, after improve- } \\
\text { ment had begun. Recovered. Second } \\
\text { analysis } 2 \text { weeks after first. }\end{array}$ \\
\hline $\begin{array}{l}\text { Few granular casts; } \\
\text { W. B. C. }\end{array}$ & Liquid & $\begin{array}{r}92.2 \\
169.0\end{array}$ & $\begin{array}{r}72.8 \\
114.0\end{array}$ & $\begin{array}{l}\text { Acute obstruction due to band, } 3 \text { days } \\
\text { duration. Relieved by operation, } 4 / 1 / 14 \text {, } \\
\text { date of first blood analysis, Mental con- } \\
\text { fusion, apathy, but no convulsions or } \\
\text { coma. Second analysis, } 4 / 10 / 14 \text {. Died, } \\
4 / 11 / 14 \text {. }\end{array}$ \\
\hline $\begin{array}{l}\text { Few hyaline, granu- } \\
\text { lar casts; many } \\
\text { W. B.C. }\end{array}$ & Liquid & $\begin{array}{r}150.3 \\
27.6\end{array}$ & $\begin{array}{l}92.0 \\
15.4\end{array}$ & $\begin{array}{l}\text { Prostatectomy, } 4 / 9 / 14 \text {, followed by para- } \\
\text { lytic ileus lasting several days. First } \\
\text { blood analysis, } 4 / 12 / 14 \text {; second, } 5 / 1 / 14 \text {. } \\
\text { Recovered. }\end{array}$ \\
\hline $\begin{array}{l}\text { Occasional hyaline } \\
\text { cast; W. B. C. }\end{array}$ & Mixed & 30.4 & 13.9 & Duration, 3 days. \\
\hline
\end{tabular}

There is an enormous increase in the secretion into the intestine, and owing to the stagnation of the intestinal contents, a marked increase in the decomposition of nitrogenous substances, as shown by the large amounts of indican in the urine. There is therefore an opportunity for increased absorption of non-protein nitrogen from the intestine. The profound shock and the possible intoxication by poisonous substances absorbed from the intestine (cf. Whipple ${ }^{17}$ ) must affect unfavorably the renal function, leading to defective elimination of waste products. And, lastly, the great loss of fluid by vomiting, ${ }^{18}$ with the resulting concentration of the blood, is undoubtedly a factor,

17. Whipple, Stone and Bernheim: Jour. Exper. Med., 1913, xvii, 286.

18. Hartwell, John A., Hoguet, J. P., and Beekman, Fenwick: An Experimental Study of Intestinal Obstruction, The Archives Int. Med., 1914, xiii, 701. 
though not enough in itself to account for a five-fold increase in the total non-protein nitrogen.

\section{DISEASES OF THE HEART AND AORTA}

Three cases of pericarditis with effusion and a case of severe acute endocarditis ending in recovery, all showed normal figures, as did also a compensated case of extensive mitral and aortic valvular disease, and a patient with aortic aneurysm. A typical case of subacute infective endocarditis (Case 63) with anemia and enormous spleen (1035

TABLE 7.-Diseases oF-

\begin{tabular}{|c|c|c|c|c|c|c|c|c|}
\hline \multirow[b]{2}{*}{$\begin{array}{l}\text { Case } \\
\text { No. }\end{array}$} & \multirow[b]{2}{*}{ Sex } & \multirow[b]{2}{*}{ Age } & \multirow[b]{2}{*}{ Diagnosis } & \multirow{2}{*}{$\begin{array}{l}\text { Sys- } \\
\text { tolic } \\
\text { Blood- } \\
\text { Pressure } \\
\text { mm. } \\
\text { Hg }\end{array}$} & \multicolumn{4}{|c|}{ Urine } \\
\hline & & & & & $\begin{array}{c}\text { Phenol- } \\
\text { sulphone- } \\
\text { phthalein } \\
\% \text { in } 2 \text { hrs. }\end{array}$ & $\begin{array}{l}\text { Amt. } \\
\text { c.c. } \\
\text { in } 24 \\
\text { hours }\end{array}$ & Sp.Gr. & Alb. \\
\hline 58 & M & $8 !$ & Pericarditis with effu- & 88 & 80 & 270 & 1.022 & S.P.T. \\
\hline 59 & M & 17 & $\begin{array}{l}\text { sion, rheumatic } \\
\text { Pericarditis with effu- } \\
\text { sion, rheumatic }\end{array}$ & 140 & 68 & 740 & 1.028 & S.P.T. \\
\hline 60 & M & 38 & $\begin{array}{l}\text { Pericarditis with effu- } \\
\text { sion, tuberculous }\end{array}$ & 110 & 37 & 1,280 & 1.018 & V.S.T. \\
\hline 61 & $\mathrm{~F}$ & 23 & Endocarditis, chronic.... & 127 & 63 & S.S. & 1.019 & S.P.T. \\
\hline 62 & $\mathrm{~F}$ & 19 & Endocarditis, acute...... & 146 & 54 & $350+$ & 1.019 & S. T. \\
\hline 63 & M & 22 & Endocarditis, malignant. & 115 & 45 & 925 & 1.011 & S. T. \\
\hline 64 & M & 55 & Aneurysm of aorta... & 140 & 70 & 500 & 1.023 & V.S.T. \\
\hline
\end{tabular}

gm.) showed considerable retention. At the necropsy the kidneys showed recent infarcts and multiple pin-point-sized hemorrhages. Microscopically, there were the signs of an acute diffuse nephritis, and many glomeruli showed hemorrhages into the capsular space. One miliary abscess was seen.

The results in cardiac decompensation have been stated already under the heading "chronic passive hyperemia of the kidneys."

\section{THE ACUTE INFECTIONS}

A. Pneumonia.-In acute lobar pneumonia we have found a moderate degree of retention in the majority of the cases, nine out of fourteen patients showing more than $35 \mathrm{mg}$. of nitrogen; the highest figure was $50 \mathrm{mg}$. The retention reached its maximum toward the 
crisis and disappeared early in convalescence. It was not dependent on the absorption of the exudate, for it occurred before resolution took place. The figures were lower in the younger patients, three out of the four under 20 years of age showing normal values. There was no apparent relation between the degree of retention and prognosis.

$B$. Typhoid Fever. - In typhoid we have met normal or slightly elevated figures in the small series studied (five cases). This is in agreement with the infrequency of severe lesions of the kidney in typhoid.

-THE Heart AND AORTA

\begin{tabular}{|c|c|c|c|c|}
\hline Urine & & \multicolumn{2}{|c|}{ Blood } & \multirow[b]{2}{*}{ Remarks } \\
\hline Microscopical & Diet & $\mid \begin{array}{c}\text { Total } \\
\mathrm{N} . \\
\text { (mg.) }\end{array}$ & $\begin{array}{c}\text { Urea } \\
\text { N. } \\
(\mathrm{mg} .)\end{array}$ & \\
\hline $\begin{array}{l}\text { Few hyaline casts; } \\
\text { W. B. C. }\end{array}$ & Soft & 22.7 & 11.0 & Chronic mitral disease. Recovered. \\
\hline W. B. C. . . . . W & Soft & 23.2 & 11.5 & $\begin{array}{l}\text { Chronic mitral and aortic disease. De- } \\
\text { veloped pleural effusion and pneumonia } \\
\text { later. Recovered. }\end{array}$ \\
\hline $\begin{array}{l}\text { Occasional hyaline } \\
\text { cast; R. B. C.; } \\
\text { many W. B. C. }\end{array}$ & Soft & 29.2 & 15.7 & $\begin{array}{l}\text { Lymphocytosis in pericardial fluid. Tap. } \\
\text { ped several times. }\end{array}$ \\
\hline $\begin{array}{l}\text { Hyaline casts; few } \\
\text { R. B. C.; many } \\
\text { W. B. C. }\end{array}$ & Mixed & 30.2 & 14.8 & $\begin{array}{l}\text { Mitral and aortic stenosis and insuffi. } \\
\text { ciency, compensated. Rheumatic. }\end{array}$ \\
\hline $\begin{array}{l}\text { Occasional hyaline } \\
\text { cast; R. B. C.; } \\
\text { W. B. C. }\end{array}$ & Mixed & 30.2 & 16.1 & $\begin{array}{l}\text { Acute aortic endocarditis, with fever last. } \\
\text { ing } 7 \text { weeks. Recovered. }\end{array}$ \\
\hline $\begin{array}{l}\text { Few hyaline, granu- } \\
\text { lar, pus casts; } \\
\text { R. B. C.; W. B. C. }\end{array}$ & Soft & 68.0 & 42.5 & $\begin{array}{l}\text { Typical subacute infective endocarditis. } \\
\text { At necropsy, kidneys showed recent in- } \\
\text { farcts and acute diffuse nephritis. }\end{array}$ \\
\hline $\begin{array}{l}\text { Occasional hyaline } \\
\text { cast; W. B. C. }\end{array}$ & Soft & 30.9 & 16.1 & No failure of compensation. \\
\hline
\end{tabular}

C. Acute Articular Rheumatism.-This has yielded very low figures, probably because of the small amount of nourishment taken by these patients and the lack of renal involvement.

$D$. Scarlet Fever.-In scarlatina, contrary to our expectations, there was not the slightest retention in any of the four cases studied. None of these, to be sure, was very severe.

\section{SYPHILIS}

We have examined eleven cases of this disease, two in the primary, four in the secondary and five in the tertiary stage. In every case in which the urine was examined, albumin and casts were found.

Of the primary cases, one was normal, the other moderately elevated (36 mg.). 
TABLE 8.-ACUTE-

\begin{tabular}{|c|c|c|c|c|c|c|c|c|c|}
\hline \multirow{2}{*}{$\begin{array}{c}\text { Case } \\
\text { No. }\end{array}$} & \multirow[b]{2}{*}{ Sex } & \multirow[b]{2}{*}{ Age } & \multirow[b]{2}{*}{ Diagnosis } & \multirow[b]{2}{*}{$\begin{array}{l}\text { Day } \\
\text { of } \\
\text { Dis- } \\
\text { ease }\end{array}$} & \multirow{2}{*}{$\begin{array}{c}\text { Sys- } \\
\text { tolic } \\
\text { Blood } \\
\text { Pressure } \\
\text { mm. } \\
\mathrm{Hg}\end{array}$} & \multicolumn{4}{|c|}{ Urine } \\
\hline & & & & & & $\begin{array}{l}\text { Phenol- } \\
\text { sulphone- } \\
\text { iphthalein } \\
\% \text { in } 2 \text { hrs. }\end{array}$ & $\begin{array}{l}\text { Amt. } \\
\text { c.c. } \\
\text { in } 24 \\
\text { hours }\end{array}$ & Sp.Gr. & Alb. \\
\hline 65 & M & 17 & Pneumonia, acute lobar & 5 & 140 & .. & S.S. & 1.023 & $0.1 \%$ \\
\hline 66 & M & 9 & Pneumonia, acute lobar & 4 & 85 & 68 & 365 & 1.024 & S.P.T. \\
\hline 67 & $\mathrm{~F}$ & 16 & Pneumonia, acute lobar & $\begin{array}{l}5 \\
7\end{array}$ & $\begin{array}{l}125 \\
\ldots\end{array}$ & $\begin{array}{l}35 \\
\cdots\end{array}$ & 750 & 1.026 & $\begin{array}{l}0.05 \% \\
\ldots \ldots\end{array}$ \\
\hline 68 & M & 33 & Pneumonia, acute lobar & $\begin{array}{c}9 \\
\cdots\end{array}$ & $\cdots$ & $\ddot{50}$ & $\dddot{4} \ddot{4} \dot{0}$ & 1.017 & S. $\dddot{P} . \mathrm{T}$ \\
\hline 69 & M & 27 & Pneumonia, acute lobar & 6 & ... & 80 & 1,520 & 1.016 & S.P.T. \\
\hline 70 & M & 36 & Pneumonia, acute lobar & 8 & 108 & 30 & 670 & 1.024 & S. T. \\
\hline $\begin{array}{l}71 \\
72\end{array}$ & $\begin{array}{l}\mathrm{M} \\
\mathrm{M}\end{array}$ & $\begin{array}{l}28 \\
39\end{array}$ & $\begin{array}{l}\text { Pneumonia, acute lobar } \\
\text { Pneumonia, acute lobar }\end{array}$ & $\begin{array}{r}4 \\
4\end{array}$ & $\begin{array}{l}\dddot{13} \dot{3} \\
108\end{array}$ & $\begin{array}{l}\ddot{ } \\
\cdots\end{array}$ & $\ddot{7700}$ & $\begin{array}{l}\dddot{1.024} \\
1.026\end{array}$ & S.P.T. \\
\hline 73 & M & 39 & Pneumonia, acute lobar & 6 & 85 & .. & 450 & 1.017 & S.P.T. \\
\hline 74 & M & 25 & Pneumonia, acute lobar & $\begin{array}{r}8 \\
15\end{array}$ & $\begin{array}{l}120 \\
\cdots\end{array}$ & $\begin{array}{l}60 \\
\cdots\end{array}$ & $\begin{array}{l}850 \\
\cdots\end{array}$ & $\begin{array}{l}1.026 \\
\cdots \cdots\end{array}$ & $\begin{array}{l}\text { S.P.T. } \\
\text { A.P. }\end{array}$ \\
\hline 75 & $\mathrm{M}$ & 51 & Pneumonia, acute lobar & $8 ?$ & 140 & .. & 1,730 & 1.016 & S.T. \\
\hline 76 & $\mathrm{M}$ & 48 & Pneumonia, acute lobar & $13 ?$ & 160 & . & 680 & 1.020 & S.P.T. \\
\hline 77 & M & 15 & Pneumonia, acute lobar & .. & $\ddot{8} \ddot{8}$ & $\ddot{80}$ & $\dddot{385}$ & $\dddot{1} \ddot{1} \ddot{2} 2$ & $\ddot{V} \ddot{\text { V.T.T. }}$ \\
\hline 78 & $\mathrm{~F}$ & 40 & Pneumonia, acute lobar & 10 & 102 & 41 & S.S. & 1.020 & V.S.T. \\
\hline 79 & $\mathrm{~F}$ & 18 & Typhoid fever & 16 & 100 & 61 & 730 & 1.016 & S.P.T. \\
\hline 80 & M & 15 & Typhoid fever ... & 19 & 105 & $\ddot{\sigma}$ & 730 & 1.021 & S.P.T. \\
\hline 81 & M & 36 & Typhoid fever & 17 & 105 & 67 & 10040 & $\ddot{1.0} \ddot{17}$ & V.̊.s. \\
\hline 82 & $\mathrm{~F}$ & 10 & Typhoid fever ........ & 12 & 115 & 71 & 270 & 1.020 & V.S.T. \\
\hline 83 & M & 30 & Typhoid fever & 20 & 90 & . & S.S. & 1.025 & $0.05 \%$ \\
\hline 84 & $\mathrm{~F}$ & 23 & $\begin{array}{l}\text { Acute articular rheu- } \\
\text { matism }\end{array}$ & 3 & 110 & .. & 700 & 1.020 & S.P.T. \\
\hline 85 & M & 28 & $\begin{array}{l}\text { Acute articular rheu- } \\
\text { matism }\end{array}$ & 16 & 112 & 70 & 640 & 1.026 & S.P.T. \\
\hline $\begin{array}{l}86 \\
87\end{array}$ & $\begin{array}{l}\mathrm{F} \\
\mathrm{F}\end{array}$ & $\begin{array}{l}23 \\
19\end{array}$ & $\begin{array}{l}\text { Erythema nodosum } . . . \\
\text { Puerperal sepsis } . . . .\end{array}$ & $\begin{array}{l}21 \\
\cdots\end{array}$ & $\begin{array}{l}100 \\
102\end{array}$ & 50 & $\begin{array}{l}575 \\
350\end{array}$ & $\begin{array}{l}1.020 \\
1.013\end{array}$ & S.P.T. \\
\hline 88 & $\mathrm{M}$ & 19 & Scarlatina & 5 & .. & .. & S.S. & 1.025 & S.P.T. \\
\hline $\begin{array}{l}89 \\
90 \\
91 \\
92 \\
93\end{array}$ & $\begin{array}{l}\mathrm{F} \\
\mathrm{M} \\
\mathrm{M} \\
\mathrm{M} \\
\mathrm{M}\end{array}$ & $\begin{array}{l}10 \\
23 \\
14 \\
19 \\
18\end{array} \mid$ & $\begin{array}{l}\text { Scarlatina } \ldots \ldots \ldots \ldots \ldots \\
\text { Scarlatina } \\
\text { Scarlatina } \\
\text { Measles } \ldots \ldots \ldots \ldots \ldots \ldots \ldots \ldots \\
\text { Meningococcus menin- } \\
\text { gitis }\end{array}$ & $\begin{array}{c}4 \\
4 \\
4 \\
6 \\
\cdots\end{array}$ & $\begin{array}{l}\cdots \\
\cdots \\
\cdots \\
138\end{array}$ & $\begin{array}{l}\because \\
\ddot{0} \\
\ddot{4} 5 \\
50\end{array}$ & $\begin{array}{r}870 \\
800 \\
825 \\
1,670 \\
835\end{array}$ & $\begin{array}{l}1.018 \\
1.025 \\
1.018 \\
1.020 \\
1.021\end{array}$ & $\begin{array}{l}\text { S.P.T. } \\
\text { S.P.T. } \\
\text { S.P.T. } \\
\text { S.P.T. } \\
\text { S.P.T. }\end{array}$ \\
\hline 94 & $\mathbf{M}$ & 23 & $\begin{array}{l}\text { gitis } \\
\text { Appendicitis with retro- } \\
\text { cecal abscess }\end{array}$ & 2 & 115 & . & S.S. & 1.025 & 0.0 \\
\hline
\end{tabular}

* The typhoid diet employed is a generous one of about 3,000 calories, containing 


\begin{tabular}{|c|c|c|c|c|}
\hline Urine & & \multicolumn{2}{|c|}{ Blood } & \multirow[b]{2}{*}{ Remarks } \\
\hline Microscopical & Diet & $\begin{array}{c}\text { Total } \\
\mathrm{N} . \\
(\mathrm{mg} .)\end{array}$ & $\begin{array}{c}\text { Urea } \\
\text { N. } \\
(\mathrm{mg} .)\end{array}$ & \\
\hline $\begin{array}{l}\text { Many brown granu. } \\
\text { lar casts; R. B.C.; } \\
\text { W. B. C. }\end{array}$ & Liquid & 23.2 & 11.2 & Died on seventh day. \\
\hline W. B. C. $\cdots \cdots \cdots \cdots$ & Soft & $\begin{array}{l}23.1 \\
24.0\end{array}$ & $\begin{array}{l}11.8 \\
12.6\end{array}$ & $\begin{array}{l}\text { Crisis ended next day. Moderately severe } \\
\text { case. Recovered. }\end{array}$ \\
\hline $\begin{array}{l}\text { Few hyaline, granu- } \\
\text { lar casts }\end{array}$ & Liquid & $\begin{array}{l}27.0 \\
23.0 \\
28.5\end{array}$ & $\begin{array}{l}14.0 \\
13.4 \\
13.4\end{array}$ & $\begin{array}{l}\text { First normal temperature on ninth day. } \\
\text { Severe case. Recovered. }\end{array}$ \\
\hline $\begin{array}{l}\text { Few granular casts; } \\
\text { W. B. C. }\end{array}$ & Soft & 28.1 & 14.3 & Died 2 days later. \\
\hline $\begin{array}{l}\text { Occasional hyaline } \\
\text { cast; W. B. C. }\end{array}$ & Soft & 30.0 & 16.6 & Recovered. \\
\hline $\begin{array}{l}\text { Granular casts; } \\
\text { W. B.C. }\end{array}$ & Soft & $\begin{array}{l}31.7 \\
40.5\end{array}$ & $\ddot{2} \ddot{7} . \dot{6}$ & $\begin{array}{l}\text { Acute followed by chronic pneumonia and } \\
\text { failure of resolution. Recovered. }\end{array}$ \\
\hline W. B. C. $\ldots \ldots \ldots \ldots$ & Soft & 33.5 & 18.4 & Crisis next day. Recovered. \\
\hline $\begin{array}{l}\text { Many hyaline casts; } \\
\text { W. B. C. }\end{array}$ & Soft & 36.2 & 19.1 & Recovered. \\
\hline $\begin{array}{l}\text { Many granu } 1 \text { a } \mathrm{r} \\
\text { casts; R. B. C.; } \\
\text { W. B.C. }\end{array}$ & Soft & 39.2 & 30.3 & Died 4 days later. \\
\hline $\begin{array}{l}\text { Hyaline, granular } \\
\text { casts R. B. C.; } \\
\text { W. B. C. }\end{array}$ & Soft & $\begin{array}{l}40.2 \\
32.4\end{array}$ & $\begin{array}{l}26.9 \\
19.0\end{array}$ & Recovered. \\
\hline $\begin{array}{l}\text { Hyaline, granular } \\
\text { casts; W. B. C. }\end{array}$ & Soft & 41.0 & 27.8 & Died 13 days later. \\
\hline $\begin{array}{l}\text { Granular cast s; } \\
\text { W. B. C. }\end{array}$ & Soft & $\begin{array}{l}41.5 \\
44.0\end{array}$ & $\begin{array}{l}24.1 \\
31.7\end{array}$ & Died 6 days after first blood analysis. \\
\hline $\begin{array}{l}\text { Hyaline, granular } \\
\text { casts; W. B. C. }\end{array}$ & Soft & $\begin{array}{l}43.7 \\
50.0 \\
31.2\end{array}$ & $\begin{array}{l}30.9 \\
36.6 \\
19.6\end{array}$ & $\begin{array}{l}3 / 6 / 14 \text {. } \\
3 / 9 / 14 \text {. After crisis. } \\
3 / 13 / 14 \text {. Crisis } 2 \text { days after first analysis. } \\
\text { Recovered. }\end{array}$ \\
\hline $\begin{array}{l}\text { Hyaline, granular } \\
\text { casts; W. B. C. }\end{array}$ & Liquid & $\begin{array}{l}46.2 \\
44.0\end{array}$ & $\begin{array}{l}30.0 \\
25.3\end{array}$ & $\begin{array}{l}\text { Complicated with jaundice. Crisis on } \\
\text { eleventh day. Recovered. }\end{array}$ \\
\hline $\begin{array}{l}\text { No casts; f e w } \\
\text { R. B. C.; W. B. C. }\end{array}$ & Soft & 21.1 & 10.1 & Temp. $103.8 \mathrm{~F}$. Moderately severe. \\
\hline Rare hyaline cast; & Typhoid* & 27.0 & 13.7 & 4/ 4/14. Temp. $104 \mathrm{~F}$. \\
\hline $\begin{array}{l}\text { R. B. C.; W. B. C. } \\
\text { Occasional hyaline } \\
\text { cast; few R.B.C.; }\end{array}$ & $\begin{array}{l}\text { Soft; } \\
\text { forced liq. }\end{array}$ & $\begin{array}{l}25.6 \\
27.2\end{array}$ & $\begin{array}{l}12.9 \\
13.3\end{array}$ & $\begin{array}{l}\text { 4/27/14. Temp. } 100 \mathrm{~F} \text {. Moderately severe. } \\
\text { Temp. } 102 \mathrm{~F} \text {. Moderately severe. }\end{array}$ \\
\hline $\begin{array}{l}\text { Few hyaline casts; } \\
\text { few R.B.C.; many } \\
\text { W. B.C. }\end{array}$ & Typhoid* & 29.2 & 15.8 & Temp. $103 \mathrm{~F}$. Moderately severe. \\
\hline $\begin{array}{l}\text { Many hyaline, gran- } \\
\text { ular casts }\end{array}$ & Liquid & 33.5 & 19.2 & $\begin{array}{l}\text { Temp. } 103 \mathrm{~F} \text {. Died on thirty-ninth day of } \\
\text { disease. }\end{array}$ \\
\hline W. B. C. ......... & Soft & 19.6 & 9.4 & Moderately severe. \\
\hline $\begin{array}{l}\text { Hyaline casts; rare } \\
\text { R. B. C.; W. B. C. }\end{array}$ & Soft & 27.4 & 15.4 & Moderately severe. \\
\hline Many W. B. C. ... & Liquid & 22.7 & 11.5 & Prolonged fever. \\
\hline Pus $\ldots \ldots \ldots \ldots \ldots$ & $\begin{array}{l}\text { Soft, with } \\
\text { meat once } \\
\text { daily }\end{array}$ & 22.5 & 11.1 & Recovered. \\
\hline $\begin{array}{l}\text { Occasional hyaline } \\
\text { cast; R. B. C. }\end{array}$ & $\begin{array}{l}\text { Moderate } \\
\text { protein. } \dagger\end{array}$ & 21.2 & 11.7 & Mild case. \\
\hline Negative ......... & Soft & 23.2 & 10.9 & Moderately severe. \\
\hline 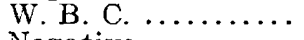 & Mixed & 27.7 & 13.8 & Moderately severe. \\
\hline $\begin{array}{l}\text { Negative } \ldots \ldots \ldots \ldots \\
\text { Negative } \ldots \ldots \ldots\end{array}$ & $\begin{array}{l}\text { Soft } \\
\text { Mixed }\end{array}$ & $\begin{array}{l}29.1 \\
27.4\end{array}$ & $\begin{array}{l}14.1 \\
18.4\end{array}$ & Mild case. \\
\hline R. B. C.; $\ddot{\mathrm{W}} \cdot \ddot{\mathrm{B}} \cdot \ddot{\mathrm{C}}$ & Soft & 27.3 & 15.6 & $\begin{array}{l}\text { Severe case. Treated with serum. Temp. } \\
104 \mathrm{~F} \text {. on day of analysis. Recovered. }\end{array}$ \\
\hline $\begin{array}{l}\text { No casts; few } \\
\text { R. B. C.; many } \\
\text { W. B. C. }\end{array}$ & Soft & 29.7 & 18.0 & \\
\hline
\end{tabular}

$100 \mathrm{gm}$. protein. $\quad \dot{\dagger}$ No meat or fish. 
The majority of those in the secondary stage was also normal, only one showing an increase (41 mg.).

In the tertiary stage there was more evidence of retention, one case showing $51 \mathrm{mg}$., another $55 \mathrm{mg}$. of nitrogen, while the remaining three were normal.

For the whole series we find 36 per cent. with a total non-protein nitrogen of $35 \mathrm{mg}$. or more. Folin and Denis, ${ }^{19}$ in a much larger series of 63 cases, reported 46 per cent. showing $35 \mathrm{mg}$. or more; their highest figure was $45 \mathrm{mg}$. Their patients were in all stages of the disease ; no clinical details are given.

TABLE 9.-

\begin{tabular}{|c|c|c|c|c|c|c|c|c|}
\hline \multirow[b]{2}{*}{$\begin{array}{l}\text { Case } \\
\text { No. }\end{array}$} & \multirow[b]{2}{*}{ Sex } & \multirow[b]{2}{*}{ Age } & \multirow[b]{2}{*}{ Diagnosis } & \multirow{2}{*}{$\begin{array}{l}\text { Sys- } \\
\text { tolic } \\
\text { Blood- } \\
\text { Pressure } \\
\text { mm. } \\
\text { Hg }\end{array}$} & \multicolumn{4}{|c|}{ Urine } \\
\hline & & & & & $\begin{array}{l}\text { Phenol- } \\
\text { sulphone- } \\
\text { phthalein } \\
\% \text { in } 2 \text { hrs. }\end{array}$ & $\begin{array}{l}\text { Amt. } \\
\text { c.c. } \\
\text { in } 24 \\
\text { hours }\end{array}$ & Sp.Gr. & Alb. \\
\hline 95 & M & 26 & Primary .. & 102 & 64 & 1,150 & 1.013 & V.S.T. \\
\hline 96 & $\mathrm{M}$ & 34 & Primary & $\ldots$ & 70 & 1,300 & 1.017 & V.S.T. \\
\hline 97 & M & 28 & Secondary .. & ... & .. & $\ldots \ldots$ & $\ldots \ldots$ & $\ldots \ldots$ \\
\hline 98 & $\mathrm{~F}$ & 38 & Secondary & ... & .. & $\ldots \ldots$ & $\ldots \ldots$ & $\ldots \ldots$ \\
\hline 99 & $\mathrm{~F}$ & 24 & Secondary .. & $\ldots$ & .. & $\ldots \ldots$ & $\ldots \ldots$ & $\ldots \ldots$ \\
\hline $\begin{array}{l}100 \\
101\end{array}$ & $\begin{array}{l}\mathrm{M} \\
\mathrm{M}\end{array}$ & $\begin{array}{l}47 \\
46\end{array}$ & $\begin{array}{l}\text { Secondary, early } \ldots \\
\text { Tertiary } \ldots \ldots \ldots \ldots\end{array}$ & 130 & .. & $\because \ddot{460}$ & $\dddot{1.026}$ & V. \\
\hline 102 & M & 42 & Tertiary & 160 & 60 & 910 & 1.030 & $0.2 \%$ \\
\hline 103 & $\mathrm{~F}$ & 45 & Tertiary & 110 & .. & (?) 220 & 1.023 & S.P.T. \\
\hline 104 & M & 28 & Tertiary & $\cdots$ & .. & S.S. & 1.015 & S.P.T. \\
\hline 105 & M & 53 & Tertiary .... & $\ldots$ & .. & S.S. & 1.024 & S.P.T. \\
\hline
\end{tabular}

From these data it seems fair to conclude that the kidneys are affected in a very considerable proportion of cases in all stages of the disease. This involvement is probably temporary as a rule, but may often go on to permanent changes in the kidney, usually of the interstitial type. Further investigation along these lines is desirable. The effect of antisyphilitic treatment, especially salvarsan, should be studied.

19. Folin, O., and Denis, W.: Jour. Biol. Chem., 1913, xiv, 29. 


\section{TUBERCULOSIS}

Out of three cases of pulmonary tuberculosis, all advanced and active, two showed a considerable retention. The study of a large series should yield interesting results.

\section{$X$. DISEASES OF THE NERVOUS SYSTEM}

Cerebral hemorrhage (including one case of skull fracture) has not been accompanied by any notable azotemia. It is thus possible to distinguish between apopleptic and uremic coma by means of blood. analysis.

-Syphilis

\begin{tabular}{|c|c|c|c|c|}
\hline Urine & & B1c & ood & \multirow[b]{2}{*}{ Remarks } \\
\hline Microscopica1 & Diet & $\begin{array}{c}\text { Total } \\
\text { N. } \\
\text { (mg.) }\end{array}$ & $\begin{array}{l}\text { Urea } \\
\text { N. } \\
\text { (mg.) }\end{array}$ & \\
\hline \multirow{4}{*}{$\begin{array}{l}\text { Hyaline, fine granu- } \\
\text { lar casts; W.B.C. }\end{array}$} & Mixed & 29.5 & 14.9 & \multirow{2}{*}{$\begin{array}{l}\text { Chancre } 3 \text { weeks ago. Wassermann }++ \text {. } \\
\text { Untreated. } \\
\text { One dose of neosalvarsan, } 16 \text { days ago. }\end{array}$} \\
\hline & Mixed & 36.0 & 19.6 & \\
\hline & Mixed & 23.7 & 14.0 & $\begin{array}{l}\text { Chancre } 1 \text { year ago. Now mucous patches } \\
\text { in mouth. Untreated. }\end{array}$ \\
\hline & Mixed & 24.1 & 10.4 & $\begin{array}{l}\text { Sore throat for } 2 \text { months. Mucous patches } \\
\text { on tongue and tonsils; spirochetes in } \\
\text { same. Untreated. }\end{array}$ \\
\hline & Mixed,low & 26.8 & 15.1 & Flat papular syphilid, generalized. Sal- \\
\hline Few granular casts & $\begin{array}{l}\text { Mixed } \\
\text { Soft }\end{array}$ & $\begin{array}{l}41.0 \\
25.7\end{array}$ & $\begin{array}{l}21.3^{\mid} \\
12.8\end{array}$ & $\begin{array}{l}\text { Chancre on chin. Roseola. Untreated. } \\
\text { Epileptiform seizures, followed by paral. } \\
\text { ysis of arm. Blood and spinal Wasser- }\end{array}$ \\
\hline $\begin{array}{l}\text { Granular casts; } \\
\text { W. B. C. }\end{array}$ & Purin free & $\begin{array}{l}28.0 \\
26.2\end{array}$ & 13.7 & $\begin{array}{l}\text { mann negative. } \\
\text { 1/24/14. Aneurysm of aorta; nephrolithia. } \\
2 / 4 / 14 \text {. sis. Wassermann }+ \text {. }\end{array}$ \\
\hline $\begin{array}{l}\text { Rare hyaline cast } \\
\text { W. B. C. }\end{array}$ & Mixed & 28.5 & 14.0 & $\begin{array}{l}\text { Obstinate headaches; relieved later by } \\
\text { salvarsan. }\end{array}$ \\
\hline $\begin{array}{l}\text { Hyaline, granular } \\
\text { casts; R. B. C. } \\
\text { W. B. C. }\end{array}$ & Mixed & 51.2 & 28.1 & Periostitis. Infection 14 years ago. \\
\hline $\begin{array}{l}\text { Hyaline, granular } \\
\text { casts; W. B. C. }\end{array}$ & $\begin{array}{l}\text { Mixed, lit. } \\
\text { tle meat }\end{array}$ & 55.0 & 35.9 & $\begin{array}{l}\text { Extensive ulceration of soft palate. Dura- } \\
\text { tion } 1 \text { year. Liver and spleen both en. } \\
\text { larged. }\end{array}$ \\
\hline
\end{tabular}

Neurasthenia and hysteria have shown normal values, as was to be expected. The three cases of hysteria were all studied immediately after an attack of convulsions.

\section{Miscellaneous disEases}

A. The Anemias.-Three of the four cases of anemia have shown a considerable degree of azotemia. In two of these hemolysis was very evident, and the retention may perhaps be explained by the clog- 
ging of the tubules of the kidney with hemoglobin and disintegrated red cells, such as has been demonstrated in fatal cases of "black-water fever." This would apply especially to Case 121, in which hemoglobinuria and reduction of the red count to one million occurred in a case of atypical lobar pneumonia due to the pneumococcus. In the other case of hemolytic anemia (No.122) a woman with one million, red cells, slight jaundice and an enlarged spleen, the nitrogen reached the very high figure of $109 \mathrm{mg}$., and the phenolsulphonephthalein output was nil. There was stupor, but no other sign of uremia. With improvement in the blood condition the nitrogen content returned to normal, and the phenolsulphonephthalein excretion rose to 31 per cent.

A case of polycythemia showed $44 \mathrm{mg}$. of nitrogen.

TABLE 10.

\begin{tabular}{|c|c|c|c|c|c|c|c|c|}
\hline \multirow[b]{2}{*}{$\begin{array}{l}\text { Case } \\
\text { No. }\end{array}$} & \multirow[b]{2}{*}{ Sex } & \multirow[b]{2}{*}{ Age } & \multirow[b]{2}{*}{ Diagnosis } & \multirow{2}{*}{$\begin{array}{l}\text { Sys- } \\
\text { tolic } \\
\text { Blood- } \\
\text { Pressure } \\
\text { mm. } \\
\mathrm{Hg}\end{array}$} & \multicolumn{4}{|c|}{ Urine } \\
\hline & & & & & $\begin{array}{l}\text { Phenol- } \\
\text { sulphone- } \\
\text { phthalein } \\
\% \text { in } 2 \text { hrs. }\end{array}$ & $\begin{array}{l}\text { Amt. } \\
\text { c.c. } \\
\text { in } 24 \\
\text { hours }\end{array}$ & Sp.Gr. & Alb. \\
\hline 106 & $\mathrm{~F}$ & 32 & Pulmonary ..... & 140 & 50 & $600+$ & 1.020 & S.P.T. \\
\hline 107 & $\mathrm{M}$ & 49 & Pulmonary .. & 133 & 63 & 1,220 & 1.020 & S.P.T. \\
\hline 108 & $\mathrm{M}$ & 21 & Pulmonary .. & 100 & .. & 560 & 1.027 & S.P.T. \\
\hline
\end{tabular}

B. Diabetes.-Uncomplicated cases have shown no retention. Two typical cases of diabetic coma have shown a considerable azotemia, up to $67 \mathrm{mg}$. of nitrogen, which is not surprising in such a grave disturbance of metabolism. A third case, however, with deep breathing and on the verge of coma, showed normal figures (Case 126).

$C$. Gout.-Both cases had a moderate retention, which can be referred to involvement of the kidneys in the gouty process.

D. Myxedema.-Each of the two cases of myxedema was complicated with chronic nephritis. Curiously enough, the one with very high blood-pressure showed normal values, while the other, with normal blood-pressure, had a marked azotemia (65 mg. nitrogen). This is a good illustration of the absolute lack of correspondence between the blood-pressure and the non-protein nitrogen. Folin and Seymour ${ }^{20}$ have called attention to this point.

20. Folin, O., Denis, W., and Seymour, M.: The Non-Protein Nitrogenous Constituents of the Blood in Chronic Vascular Nephritis (Arteriosclerosis) as Influenced by the Level of Protein Metabolism, Thr Archives Int. Med., 1914. xiii, 224. 
The influence of thyroid secretion on metabolism is shown by the considerable rise in non-protein nitrogen and urea in both these cases when thyroid extract was administered. The increase averaged 6.1 $\mathrm{mg}$. for the nitrogen and $4.5 \mathrm{mg}$. for the urea.

E. Exophthalmic Goiter.-Normal values were found in one case, and also in another complicated with diabetes (Case 128).

F. Malignant Disease.-One of the three cases of carcinoma showed a considerable retention; the other two were normal.

G. Acute Yellow Atrophy of the Liver.-We have examined one case of this disease (No. 137), typical in all respects except in the termination in recovery. During the height of the symptoms there was a considerable retention of waste nitrogen. The chief point of

-.TubERCulosis

\begin{tabular}{|c|c|c|c|c|}
\hline Urine & & $\mathrm{Bl}$ & ood & \\
\hline Microscopical & Diet & $\begin{array}{c}\text { Total } \\
\text { N. } \\
(\mathrm{mg} .)\end{array}$ & $\begin{array}{c}\text { Urea } \\
\text { N. } \\
\text { (mg.) }\end{array}$ & Remarks \\
\hline $\begin{array}{l}\text { Few hyaline casts; } \\
\text { R. B. C.; W. B. C. }\end{array}$ & Mixed & 22.9 & 12.7 & Temp. $101 \mathrm{~F}$. Third stage. \\
\hline $\begin{array}{l}\text { Hyaline, granular } \\
\text { easts; R. B. C.; } \\
\text { W. B. C. }\end{array}$ & Soft & 40.0 & 26.2 & $\begin{array}{l}\text { Febrile. Second stage. Profuse hemor. } \\
\text { rhage } 11 \text { days previous to analysis. }\end{array}$ \\
\hline $\begin{array}{l}\text { Occasional hyaline } \\
\text { cast; W. B. C. }\end{array}$ & Soft & 43.5 & 19.9 & Febrile. Second stage. \\
\hline
\end{tabular}

interest, however, lies in the urea, which at the first two examinations was decidedly below the normal, constituting 32 per cent. and 41 per cent. of the total nitrogen, respectively, while usually with retention there is an increase in the urea fraction, often up to 70 or 80 per cent. of the whole. This phenomenon is in accord with the diminished excretion of urea, and the supposed diminished urea formation in the liver in this disease. The last analysis, made as the patient was beginning to improve, though still deeply jaundiced, showed nearly normal figures.

The Effect of Diet in Azotemia.-Folin, Denis and Seymour ${ }^{20}$ have investigated the effect of a protein-poor diet in chronic interstitial nephritis, and found in every case a marked reduction in both nitrogen and urea, usually though not always to normal or below. Their highest figure for nitrogen was $58 \mathrm{mg}$. We also have experimented in this way in a few cases, using the protein-poor diet recommended by Goodall. ${ }^{21}$ In two cases (Nos. 12 and 36 ) a considerable retention

21. Goodall, H. W.: Boston Med. and Surg. Jour., 1913, clxviii, 760. 
of about $50 \mathrm{mg}$. nitrogen was caused to disappear by diet. In uremic patients with excessively high figures (cf. Case 16) we have not been able to reduce the azotemia to any important degree.

Prognosis and Blood Analysis.-In chronic nephritis and obstruction of the urinary tract resulting from urethral stricture and cancer of the bladder, we have found that a nitrogen value of over $90 \mathrm{mg}$. has been followed by death within a period of thirty-five days in all but one of ten cases. The exception was Case 13, previously referred to. Four patients with over $200 \mathrm{mg}$. of nitrogen all died in nineteen days or less. When, however, the condition leading to excessive reten-

TABLE 11.-Diseases-.

\begin{tabular}{|c|c|c|c|c|c|c|c|c|}
\hline \multirow[b]{2}{*}{$\begin{array}{l}\text { Case } \\
\text { No. }\end{array}$} & \multirow[b]{2}{*}{ Sex } & \multirow[b]{2}{*}{ Age } & \multirow[b]{2}{*}{ Diagnosis } & \multirow{2}{*}{$\begin{array}{l}\text { Sys- } \\
\text { tolic } \\
\text { Blood- } \\
\text { Pressure } \\
\text { mm. } \\
\text { Hg }\end{array}$} & \multicolumn{4}{|c|}{ Urine } \\
\hline & & & & & $\begin{array}{l}\text { Phenol- } \\
\text { sulphone- } \\
\text { phthalein } \\
\% \text { in } 2 \text { hrs. }\end{array}$ & $\begin{array}{l}\text { Amt. } \\
\text { c.c. } \\
\text { in } 24 \\
\text { hours }\end{array}$ & Sp. Gr. & A1b. \\
\hline 109 & M & 63 & $\begin{array}{l}\text { Fracture of skull with } \\
\text { cerebral hemorrhage }\end{array}$ & 180 & 30 & S. S. & 1.025 & V.S.T. \\
\hline 110 & $\mathrm{M}$ & 60 & Cerebral hemorrhage & 205 & 59 & S.S. & 1.030 & S.P.T. \\
\hline 111 & $\mathrm{~F}$ & 53 & Cerebral hemorrhage & 220 & 50 & S.S. & 1.027 & $0.2 \%$ \\
\hline 112 & $\mathrm{M}$ & 52 & Cerebral hemorrhage & 190 & . & S.S. & 1.020 & H. T. \\
\hline $\begin{array}{l}113 \\
114 \\
115 \\
116\end{array}$ & $\begin{array}{l}\mathrm{F} \\
\mathrm{M} \\
\mathrm{F} \\
\mathrm{F}\end{array}$ & $\begin{array}{l}43 \\
54 \\
48 \\
28\end{array}$ & 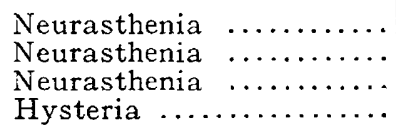 & $\begin{array}{l}140 \\
140 \\
140 \\
\cdots\end{array}$ & $\begin{array}{l}\cdots \\
\cdots \\
\cdots\end{array}$ & $\begin{array}{l}\text { S.S. } \\
\text { S.S. } \\
\text { S.S. } \\
\text { S.S. }\end{array}$ & $\begin{array}{l}1.022 \\
1.014 \\
1.012\end{array}$ & $\begin{array}{l}\text { S.P.T. } \\
\text { S.P.T. } \\
\text { S.P.T. } \\
\text { T. }\end{array}$ \\
\hline $\begin{array}{l}117 \\
118\end{array}$ & $\begin{array}{l}\mathrm{F} \\
\mathrm{F}\end{array}$ & $\begin{array}{l}38 \\
30\end{array}$ & 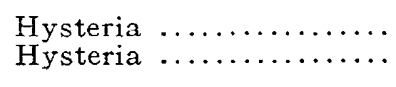 & 135 & 50 & S.S. & $\begin{array}{l}1.004 \\
1.023\end{array}$ & $\begin{array}{l}\text { S.P. T. } \\
\text { S.P.T. }\end{array}$ \\
\hline
\end{tabular}

tion is temporary, as, for instance, in acute intestinal obstruction (Case 56), or hemolytic anemia (Case 122), a total nitrogen value of even $150 \mathrm{mg}$. is not inconsistent with recovery.

\section{SUMMARY AND CONCLUSIONS}

Analyses of the blood for total non-protein nitrogen and urea nitrogen have been made by the methods of Folin in five healthy adults and 142 hospital cases.

1. In the fasting healthy adult the total non-protein nitrogen varied betweeen 22.9 and $25 \mathrm{mg}$. per 100 c.c. of blood, and the urea nitrogen between 12 and $14 \mathrm{mg}$. 
2. The effect of a full meal with meat in the case of the healthy adult was a rise of total non-protein nitrogen averaging $4.7 \mathrm{mg}$., and of urea, averaging $2.5 \mathrm{mg}$.

3. In both chronic interstitial and chronic diffuse nephritis the cases without symptoms of uremia showed normal or moderately elevated values; the uremic cases, with one possible exception, showed a great increase in both nitrogen and urea.

4. The excretion of phenolsulphonephthalein was roughly proportionate to the degree of retention; the cases with $100 \mathrm{mg}$. or over of total nitrogen all showed 5 per cent. or less phenolsulphonephthalein excretion. Many cases, however, with a considerable impairment of

-oF the Nervous System

\begin{tabular}{|c|c|c|c|c|}
\hline Urine & ! & Blc & ood & \\
\hline Microscopical & Diet & $\begin{array}{c}\text { Total } \\
\mathrm{N} . \\
\text { (mg.) }\end{array}$ & $\begin{array}{c}\text { Urea } \\
\text { N. } \\
\text { (mg.) }\end{array}$ & Remarks \\
\hline R. B. C.; W. B. C. & None & 20.2 & 10.0 & Convulsions. Fatal case. \\
\hline Few hyaline, granu- & & & & \\
\hline lar casts ......... & Soft & 27.0 & 13.7 & Recovered. \\
\hline $\begin{array}{l}\text { Hyaline, granular } \\
\text { casts; W. B. C. }\end{array}$ & Liquid & 28.7 & 14.1 & Died 45 days later. \\
\hline $\begin{array}{l}\text { Hyaline, granular } \\
\text { casts }\end{array}$ & & 36.1 & 18.6 & Died few hours later. \\
\hline No casts ... & Mixed & 22.7 & 11.5 & \\
\hline No casts...$\ldots \ldots$ & Mixed & 25.7 & & \\
\hline No casts..$\ldots \ldots \ldots$ & Mixed & 27.8 & 13.5 & \\
\hline $\begin{array}{l}\text { Numerous hyaline, } \\
\text { granular c asts; } \\
\text { W. B.C. }\end{array}$ & Mixed & 22.0 & 12.0 & Hysterical convulsions. \\
\hline No casts...$\ldots \ldots$ & Mixed & 26.5 & 14.4 & Hysterical convulsions. \\
\hline $\begin{array}{l}\text { Hy a } 1 \text { in e casts } \\
\text { W. B. C. }\end{array}$ & Soft & 27.2 & 12.0 & Hysterical convulsions. \\
\hline
\end{tabular}

phenolsulphonephthalein excretion showed no signs of retention, and a moderate amount of retention of waste nitrogen often occurred with no impairment of the elimination of phthalein.

5. The proportion of urea nitrogen to the total non-protein nitrogen in disease varied from 32 per cent. to 85 per cent. Where the nitrogen was normal the urea usually was about one-half the total nitrogen; where it was elevated, the urea usually but by no means always constituted about 70 per cent. of the whole. No reasons could be found for these variations. The determination of the total non-protein nitrogen alone is therefore more valuable than that of the urea alone. 
TABLE 12.-Miscellaneous-

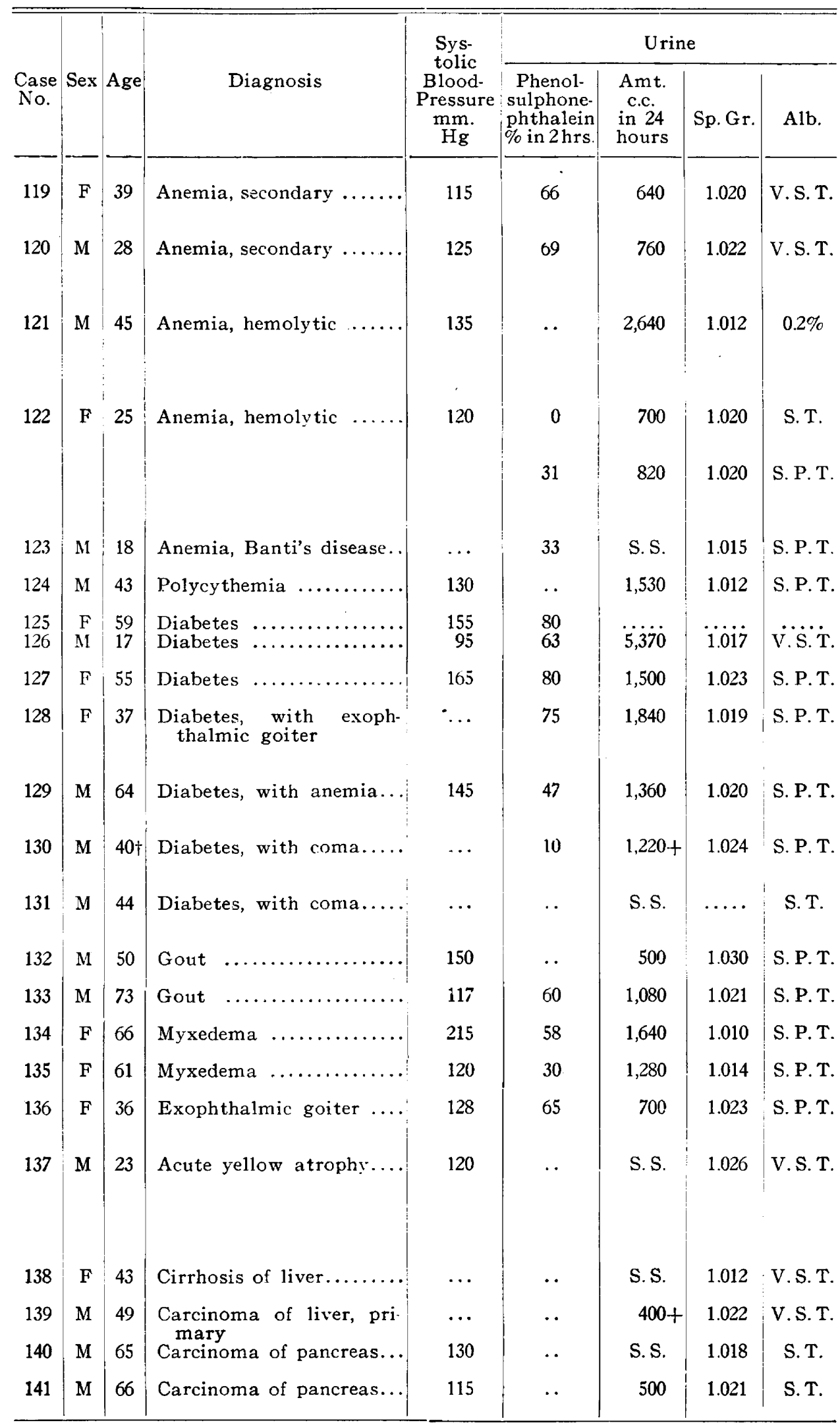

+ About. 


\begin{tabular}{|c|c|c|c|c|}
\hline Urine & & $\mathrm{Blc}$ & ood & \\
\hline Microscopical & Diet & $\begin{array}{c}\text { Total } \\
\text { N. }\end{array}$ & $\begin{array}{c}\text { Urea } \\
\text { N. } \\
(\mathrm{mg} .)\end{array}$ & Remarks \\
\hline $\begin{array}{l}\text { Occasional hyaline } \\
\text { cast; few R.B.C.; } \\
\text { W. B. C. }\end{array}$ & Mixed & 30.4 & 14.8 & $\begin{array}{l}\mathrm{Hb}, 10-15 \% ; \mathrm{R} . \mathrm{B}, \mathrm{C}, 2,160,000 ; \text { nucleater } \\
\text { reds. Uterine hemorrhage following } \\
\text { abortion. }\end{array}$ \\
\hline W. B. C. . . . . . . & Soft & 50.0 & 28.1 & $\begin{array}{l}\text { Hb., } 15 \% ; \text { R. B. C., } 1,460,000 ; \text { nucleated } \\
\text { reds. Profuse hemorrhage from stomach } \\
\text { and intestine shortly before analysis, } \\
\text { duodenal vilcer. }\end{array}$ \\
\hline $\begin{array}{l}\text { Numerous hemaglo- } \\
\text { bin casts; rare } \\
\text { R. B. C. }\end{array}$ & Liquid & 83.7 & 59.7 & $\begin{array}{l}\text { Atypical acute lobar pneumonia, compli } \\
\text { cated with hemoglobinuria setting in } \\
\text { on twelfth day, and lasting } 3 \text { days. } \\
\text { Blood analysis on fifteenth day. Red }\end{array}$ \\
\hline $\begin{array}{l}\text { Few hyaline casts; } \\
\text { few R. B. C.; } \\
\text { W. B. C. }\end{array}$ & Soft & 108.8 & 79.0 & $\begin{array}{l}\text { count, } 1,072,000 \% \\
6 / 26 / 14 \text { Hb., } 20 \% \text {; R.B.C., } 780,000 \text {; W.B.C. } \\
32,000 \text {. }\end{array}$ \\
\hline $\begin{array}{l}\text { Few hyaline casts; } \\
\text { few R. B. C.; } \\
\text { W. B. C. }\end{array}$ & Mixed & 26.1 & ... & $\begin{array}{l}\text { 7/17/14 Hb., } 60 \% \text {; R.B.C., } 2,820,000 ; \text { W.B.C } \\
6,200 \text {. At first analysis, nucleated reds } \\
\text { increased fragility of red cells; enlarged } \\
\text { spleen and slight jaundice. }\end{array}$ \\
\hline $\begin{array}{l}\text { Few hyaline casts; } \\
\text { W. B. C. }\end{array}$ & $\begin{array}{l}\text { Refused } \\
\text { food }\end{array}$ & 39.7 & 21.3 & $\begin{array}{l}\text { Hb., } 35 \% \text {; R.B.C., } 2,216,000 \text {. Died } 2 \text { days } \\
\text { later. }\end{array}$ \\
\hline $\begin{array}{l}\text { No casts; occa- } \\
\text { sional R. B. C. }\end{array}$ & Mixed & 43.7 & 24.3 & $\begin{array}{l}\text { R.B.C., 7,900,000. Enlarged spleen with } \\
\text { cyanosis. }\end{array}$ \\
\hline & Janeway & 21.1 & 13.6 & Sugar, $2.3 \%$. Moderately severe case. \\
\hline $\begin{array}{l}\text { Hyaline, granular } \\
\text { casts; R. B. C. }\end{array}$ & Janeway & 25.0 & 9.0 & $\begin{array}{l}\text { Acidosis with deep breathing. Died in } \\
\text { coma } 4 \text { days later. }\end{array}$ \\
\hline $\begin{array}{l}\text { Occasional hyaline } \\
\text { cast; W. B. C. }\end{array}$ & Janeway & 27.5 & 16.7 & $\begin{array}{l}\text { Sugar, } 5.0 \% \text { on entrance; } 0.5 \% \text { on day of } \\
\text { blood analysis. Moderately severe case. }\end{array}$ \\
\hline $\begin{array}{l}\text { Hyaline, granular } \\
\text { casts; R. B. C.; } \\
\text { W. B. C. }\end{array}$ & Janeway & 27.7 & 13.7 & $\begin{array}{l}\text { Sugar, } 4.5 \% \text { on entrance; } 0.7 \% \text { on day of } \\
\text { analysis. Developed acidosis } 2 \text { days } \\
\text { later and died suddenly the same day, } \\
\text { not in coma. }\end{array}$ \\
\hline $\begin{array}{l}\text { Rare hyaline cast; } \\
\text { W. B.C. }\end{array}$ & Janeway & 29.4 & 13.8 & $\begin{array}{l}\text { Probably pancreatic diabetes. Blood- } \\
\text { count: Hb., } 35 \% ; \text { R.B.C., } 2,400,000 \text {; no } \\
\text { nucleated reds. }\end{array}$ \\
\hline $\begin{array}{l}\text { Hyaline, granular } \\
\text { casts; R. B. C.; } \\
\text { W. B. C. }\end{array}$ & None & 45.8 & 23.3 & $\begin{array}{l}\text { Typical acid coma. Died } 36 \text { hours after } \\
\text { blood was taken. }\end{array}$ \\
\hline$\ldots \ldots \ldots \ldots \ldots$ & None & 66.9 & 44.0 & $\begin{array}{l}\text { Large amount of sugar. Typical acid } \\
\text { coma. Died few hours after blood was } \\
\text { taken. }\end{array}$ \\
\hline $\begin{array}{l}\text { H y a } 1 \text { ine casts; } \\
\text { W. B. C. }\end{array}$ & Soft & 35.1 & 21.2 & $\begin{array}{l}\text { Two attacks a number of years previous. } \\
\text { Tophus in ear. }\end{array}$ \\
\hline $\begin{array}{l}\text { Hyaline, } \\
\text { casts; R. B. C. }\end{array}$ & Soft & 38.9 & 27.0 & Typical attacks for many years. \\
\hline $\begin{array}{l}\text { Hyaline, granular } \\
\text { casts: W. B. C. }\end{array}$ & Mixed & $\begin{array}{l}23.5 \\
31.2\end{array}$ & $\begin{array}{l}11.5 \\
13.2\end{array}$ & $\begin{array}{l}\text { Without thyroid extract. } \\
\text { With thyroid } 9 \text { days. }\end{array}$ \\
\hline $\begin{array}{l}\text { Hyaline, granular } \\
\text { casts; W. B. C. }\end{array}$ & Mixed & 60.2 & $\begin{array}{l}39.8 \\
47.0\end{array}$ & $\begin{array}{l}\text { Without thyroid extract. } \\
\text { With thyroid. No renal symptoms. }\end{array}$ \\
\hline $\begin{array}{l}\text { H y } 1 \text { ine casts; } \\
\text { many R. and } \\
\text { W. B. C. }\end{array}$ & Soft & 27.7 & 13.5 & Marked symptoms of hyperthyroidism. \\
\hline $\begin{array}{l}\text { Occasional hyaline, } \\
\text { granular casts; } \\
\text { R. B. C.; W. B. C. }\end{array}$ & Liquid & $\begin{array}{l}30.4 \\
42.0 \\
44.7 \\
44.2 \\
33.1\end{array}$ & $\begin{array}{r}9.7 \\
17.1 \\
19.5 \\
23.4 \\
15.0\end{array}$ & $\begin{array}{l}5 / 22 / 14 \text { Jaundice with delirium, mania } \\
5 / 24 / 14 \text { and stupor. Liver much de- } \\
5 / 25 / 14 \text { creased in size. Leucin and } \\
5 / 26 / 14 \text { tyrosin in urine. Complete recov- } \\
5 / 27 / 14 \text { ery with return of liver to nor- } \\
\text { mal size. }\end{array}$ \\
\hline $\begin{array}{l}\text { Rare hyaline cast; } \\
\text { occasional W.B.C. }\end{array}$ & Mixed & 21.2 & 8.8 & $\begin{array}{l}\text { Large liver and spleen without ascites. } \\
\text { Alcoholism. Positive Wassermann. }\end{array}$ \\
\hline Rare granular cast & Mixed & 27.0 & 12.9 & $\begin{array}{l}\text { Died } 12 \text { days later. Diagnosis proved by } \\
\text { necropsy. }\end{array}$ \\
\hline $\begin{array}{l}\text { Hyaline, granular } \\
\text { casts; W. B. C. }\end{array}$ & Fat-free & 33.5 & 13.0 & $\begin{array}{l}\text { Jaundice with dilated gall-bladder, and } \\
\text { typical pancreatic stools. }\end{array}$ \\
\hline $\begin{array}{l}\text { Hyaline, granular } \\
\text { casts; W. B. C. }\end{array}$ & Soft & 41.4 & 22.6 & $\begin{array}{l}\text { Jaundice. Carcinoma of head of pancreas } \\
\text { at necropsy. }\end{array}$ \\
\hline
\end{tabular}


6. The estimation of the total non-protein nitrogen is of the greatest value in the diagnosis of uremia. Amounts of $100 \mathrm{mg}$. or over were encountered in only two conditions besides uremia, namely, acute intestinal obstruction and profound anemia from hemolysis. Only one case of uremia without marked increase in nitrogen was encountered out of a total of eight cases.

7. The determination of the total non-protein nitrogen is a great aid in the prognosis of chronic nephritis. Patients showing over 100 mg., with one exception, did not live more than thirty-five days.

8. The results of blood analysis furnish the best guide as to the diet to be given in nephritis; cases with a considerable retention require a restriction of the protein, and by this means a return to normal figures may be brought about, if the azotemia is not too pronounced. In cases of outspoken uremia, however, no marked reduction of the azotemia has resulted from a protein-poor diet. Nephritis with a normal amount of non-protein nitrogen does not call for any marked decrease of protein in the diet.

9. In chronic passive congestion of the kidneys there is little or no retention of nitrogenous waste products.

10. In pyelitis the presence of azotemia probably indicates involvement of the parenchyma of the kidney.

11. A marked elevation of the non-protein nitrogen or urea renders the patient a poor operative risk, and the azotemia should be overcome by diet, if possible, before an operation is attempted, in all cases in which delay is permissible. In hypertrophy of the prostate, for example, a low-protein diet may be combined with drainage of the bladder as a preliminary to operation.

12. Chronic lead-poisoning was accompanied by evidence of retention in all the cases examined.

13. The eclampsia of pregnancy seldom shows a marked increase in non-protein nitrogen and urea. It is therefore distinct from uremia. Analysis of the blood will usually serve to distinguish between uremia and eclampsia.

14. In acute intestinal obstruction a tremendous increase in the nitrogenous waste products was found in all of the three cases examined. A return to normal took place in the two which recovered.

15. Compensated valvular disease of the heart, aortic aneurysm. acute pericarditis with effusion, and acute endocarditis in the absence of disease of the kidneys, all showed normal values.

16. In acute lobar pneumonia a considerable increase was seen in the majority of cases, reaching its maximum toward the crisis, but bearing no relation to the time at which resolution took place. Typhoid 
fever, acute rheumatism and uncomplicated scarlatina showed normal figures.

17. Syphilis showed a considerable degree of retention in 36 per cent. of the cases examined, evident in all stages of the disease.

18. In cerebral hemorrhage, hysteria and neurasthenia no increase was found.

19. Severe anemia due to hemolysis showed a marked retention, reaching in one case $100 \mathrm{mg}$. of nitrogen.

20. In uncomplicated diabetes the values were normal; both cases examined in coma showed retention.

21. The administration of thyroid extract in two cases of myxedema caused an increase in both nitrogen and urea. Both cases were complicated with chronic nephritis.

22. In exophthalmic goiter the blood nitrogen and urea were normal in amount.

23. No changes were met with in malignant disease which could not be ascribed to a complication with renal disease.

24. In a case of acute yellow atrophy the proportion of urea nitrogen to the total non-protein nitrogen was decreased, although there was a considerable degree of azotemia.

In conclusion we take pleasure in acknowledging our indebtedness to Professor Folin, Dr. Henry Lyman and Dr. Richard P. Bell for helpful advice in the laboratory work, and to the staff of the New Haven Hospital for placing the clinical material at our disposal.

424 Temple Street--1193 Chapel Street. 